\title{
Analisis Persepsi Pengguna Aplikasi Transportasi Grab terhadap Perilaku Menggunakan Alat pembayaran $\mathrm{OVO}$
}

\author{
Katarina Siena ${ }^{1}$, Aurelia Melinda Nisita Wardhani ${ }^{2}$ \\ ${ }^{1}$ PT Lingkar Organik, Kalasan, D.I. Yogyakarta \\ ${ }^{2}$ Jurusan Akuntansi, Fakultas Ekonomi, Universitas Sanata Dharma \\ katarinasiena.ks@gmail.com, nisita.wardhani@usd.ac.id
}

DOI: https://doi.org/10.24071/exero.v3i1.4241

\begin{abstract}
Abstrak
Mobile Payment OVO merupakan metode pembayaran baru yang hadir di Indonesia dan bekerjasama dengan Grab pada bulan Juni 2018 sebagai metode pembayaran online. Penelitian ini bertujuan untuk mengetahui persepsi pengguna aplikasi transportasi Grab terhadap perilaku penggunaan mobile payment OVO. Jenis penelitian ini adalah studi survei. Subjek penelitian ini adalah pengguna mobile payment OVO pada transportasi online Grab di Jabodetabek dan Yogyakarta. Sampling dilakukan dengan metode snowball. Teknik pengumpulan data menggunakan metode survei, dengan menyebarkan kuesioner online dan wawancara online melalui google form. Hasil penelitian ini menunjukkan bahwa persepsi pengguna mobile payment OVO pada Grab memiliki pengaruh terhadap perilaku pengguna. Hal ini didasari oleh kemudahan jangkauan, kepercayaan, serta keamanan dan privasi pengguna saat menggunakan mobile payment OVO pada transportasi Grab.
\end{abstract}

Kata kunci: technology acceptance model, mobile payment characteristic, mobile payment knowledge, perceived security and privacy, perceived trust.

\begin{abstract}
OVO Mobile Payment is a new method of online payment which has existed and cooperated together with Grab since June 2018. This research aims to understand user's perception on Grab transportation application towards usage behavior of OVO mobile payment. The type of this research is a survey study. The research subjects are all users of OVO mobile payment who use online transportation in Jabodetabek and Yogyakarta. Sampling was collected using snowball method. The data was collected through a survey method by spreading online questionnaires and online interviews through Google Form. The result shows that user's perception of OVO mobile payment has an effect towards user's behavior. Those are caused by seamless coverage, trust, safety, and privacy of users when they use the OVO mobile payment in Grab application.
\end{abstract}

Keywords: technology acceptance model, mobile payment characteristic, mobile payment knowledge, perceived security and privacy, perceived trust.

\section{Pendahuluan}

Saat ini teknologi semakin berkembang dalam hal inovasi sehingga memberikan kemudahan manusia untuk memenuhi kebutuhan hidupnya. Kemajuan teknologi ini sangat terbantu oleh hadirnya internet karena mampu mendukung pekerjaan dan kebutuhan hidup manusia. Kebutuhan tersebut dapat berupa primer dan sekunder. Kebutuhan primer berupa pakaian, makanan dan kebutuhan lainnya yang bisa diperoleh dengan mudah melalui aplikasi berbasis internet. Melihat 
perkembangan internet sangat pesat, teknologi dan sistem informasi memberikan berbagai macam inovasi, khususnya pada transportasi. Jenis transportasi menurut bbc.com (2017) terdiri dari dua, yaitu transportasi konvensional dan transportasi online. Transportasi konvensional berupa ojek pangkalan dan angkutan umum, sedangkan transportasi online berupa Grab dan Go-Jek.

Transportasi umum yang dapat dipesan secara online saat ini sedang digemari oleh masyarakat karena mampu menunjang kebutuhan manusia dalam pemenuhan kebutuhan hidup sehari- hari. Transportasi umum menurut infopeluangusaha.org (2018) telah memberikan keuntungan bagi pengendara karena penghasilan yang cukup memberikan keuntungan yang besar. Selain praktis, masyarakat juga membutuhkan kendaraan yang cepat dan dapat terhindar dari kemacetan.

Grab (Grab.com) merupakan salah satu transportasi umum yang bisa dipesan secara online melalui aplikasi. Grab mulanya memberikan layanan transportasi online berada di Asia Tenggara. Grab hadir di Indonesia pada bulan Juni 2012 dan memberikan layanan transportasi secara online. Produk layanan yang dimiliki adalah ojek online (GrabBike), mobil (GrabCar), taksi (GrabTaxi), kurir (GrabExpress), pesan antar makanan (GrabFood), carpooling social (GrabHich Car) dan GrabGerak. Pembayaran pada Grab dapat dilakukan secara tunai maupun online. Pembayaran Grab (Kontan.co.id, 2018) menggunakan GrabPay. Namun seiring berjalannya waktu, Grab tidak menggunakan GrabPay lagi dikarenakan pihak Grab belum memiliki izin lisensi praktik electronic money dari Bank Indonesia untuk menjalankan fitur GrabPay secara penuh. Dengan adanya masalah tersebut, Grab melakukan kerjasama dengan OVO pada tahun 2017. Dompet digital OVO ini secara resmi sudah memperoleh lisensi dari Bank Indonesia untuk menyediakan layanan jasa electronic money. Bank Sentral sudah memberikan izin operasional penuh pada electronic money OVO pada 7 Agustus 2017 dan mulai beroperasional pada 22 Agustus 2017. Pembayaran secara online pada Grab melalui OVO merupakan bagian dari Financial Technology (Fintech).

Fintech diatur dalam peraturan Bank Indonesia Nomor 19/12/PBI/2017. Fintech bisa digunakan untuk membeli saham, sebagai alat pengatur keuangan, sebagai pengumpulan uang dan perencanaan uang untuk masa depan, pendukung 
pasar, manajemen investasi dan manajemen risiko, pinjaman, pembiayaan dan penyedia modal, dan jasa finansial lainnya. Seiring berjalannya waktu penggunaan dompet elektronik ini rentan mengalami penipuan seperti penipuan berupa order fiktif yang dilakukan oleh oknum driver transportasi pada Grab (merdeka.com). Kasus tersebut membuat masyarakat menimbulkan keraguan terhadap kepercayaan dan dalam penggunaan dompet elektronik.

Berdasarkan pemaparan permasalahan di atas, peneliti tertarik untuk melakukan penelitian terhadap persepsi perilaku pengguna aplikasi transportasi online Grab saat menggunakan OVO sebagai metode pembayarannya. Persepsi pengguna yang akan diukur menggunakan adalah mobile payment characteristic yang terdiri dari mobility, reachability, compatibility, dan convenience. Selanjutnya penelitian ini juga ingin melihat persepsi pengetahuan (mobile payment knowledge), perceived trust, serta perceived security and privacy yang dimiliki oleh pengguna OVO saat bertransaksi dalam aplikasi transportasi Grab. Penelitian ini diharapkan dapat memberikan keyakinan kepada pengguna transportasi online Grab untuk melakukan pembayaran transaksi melalui OVO.

Di sisi lain, penelitian ini dilatarbelakangi juga oleh penelitian terdahulu yang dilakukan oleh Davis et al. (1989) terkait model penerimaan teknologi (Technology Acceptance Model). Model ini merupakan penerimaan sistem teknologi informasi yang akan digunakan oleh pemakai (Venkatesh et al., 2003), (Kim et al., 2010), (Liu et al., 2015), dan Marakarkandy et al. (2017). Penelitian ini diharapkan berkontribusi terhadap pengguna dan masyarakat terkait dengan persepsi mereka mengenai penggunaan mobile payment OVO pada transportasi online Grab. Keamanan dan privasi yang dapat dirasakan oleh masyarakat diyakini dapat mengurangi kekhawatiran akan risiko penggunaan, seperti halnya penipuan pembayaran dan keterlambatan pelayanan serta meningkatkan kepercayaan terhadap penggunaan OVO sebagai aplikasi pembayaran transportasi online Grab.

Berdasarkan permasalahan yang telah dipaparkan diatas, peneliti memilih kota Jabodetabek dan Yogyakarta sebagai tempat penelitian karena Jabodetabek sebagai pusat kota dengan tingkat penghasilan yang tinggi dan transportasi online Grab sebagai solusi untuk mengatasi masalah kemacetan di daerah Jabodetabek. Selain itu, Jabodetabek juga menjadi kota wisata bagi wisatawan. Sementara itu, kota 
Yogyakarta dipilih dalam penelitian ini karena sebagai kota pelajar dan kota budaya yang sering menjadi tujuan destinasi para wisatawan, sehingga transportasi online Grab memberikan kepercayaan agar mudah dijangkau bagi semua kalangan masyarakat baik mahasiswa maupun wisatawan. Dengan demikian, penelitian ini berfokus untuk meneliti bagaimana persepsi pengguna aplikasi transportasi Grab terhadap perilaku penggunaan alat pembayaran secara mobile yaitu OVO.

\section{Kajian Literatur}

\section{Financial Technology}

Menurut Liudmila et al. (2016), "financial technology (fintech) merupakan asal kata yang memiliki hubungan antara "keuangan" dan "teknologi" yang menuju pada bidang baru dan inovatif baru yang menarik perhatian dari publisitas serta investasi yang terus meningkat." Di sisi lain, fintech juga memberi peluang kepada masyarakat, seperti contohnya adalah memungkinkan transparansi, mengurangi biaya, dan kemudahan untuk mengakses informasi. Sementara itu, fintech diatur dalam peraturan Bank Indonesia Nomor 19/12/PBI/2017 yaitu:

"Fintech merupakan sebuah penggunaan teknologi sistem keuangan yang bisa menghasilkan sebuah produk, layanan, teknologi, dan/atau model bisnis yang baru dan berdampak pada stabilitas moneter, stabilitas sistem keuangan, efisiensi, kelancaran, keamanan dan keandalan sistem pembayaran. Fintech dapat digunakan untuk pembelian saham, sebagai alat pengatur keuangan, sebagai pengumpulan uang dan perencanaan uang untuk masa depan, pendukung pasar, manajemen investasi dan manajemen risiko, pinjaman, pembiayaan dan penyedia modal, dan jasa finansial lainnya".

\section{Mobile Payment}

Kim (2010:312) mengungkapkan bahwa mobile payment merupakan sebuah metode pembayaran alternatif untuk transaksi barang, jasa, dan tagihan/faktur. Metode ini menggunakan perangkat seluler (seperti ponsel, ponsel pintar, atau asisten digital pribadi) dan teknologi komunikasi nirkabel (seperti jaringan telekomunikasi seluler). Selain itu, mobile payment juga dapat digunakan dalam berbagai pembayaran, seperti pembayaran untuk konten digital, tiket konser atau penerbangan, biaya parkir, tarif bus, kereta api dan taksi. Di sisi lain, Cernev et al. (2011), mengungkapkan bahwa pembayaran mobile dapat diakui sebagai alat pembayaran transaksi seperti uang digital atau yang disebut sebagai mobile money. 
Transaksi ini menggunakan ponsel yang mengacu pada transaksi melalui teknologi seluler dengan memanfaatkan jaringan telekomunikasi seluler.

Selanjutnya, Kim (2010) mengungkapkan bahwa terdapat beberapa karakteristik dari pembayaran menggunakan seluler yaitu (a) mobilitas, hal ini merupakan kemampuan untuk mengakses layanan di mana saja melalui jaringan nirkabel dalam ponsel, (b) jangkauan hal ini merupakan kemampuan seseorang dapat dihubungi oleh layanan mobile payment tanpa terbatas waktu dan tempat, serta pengguna diberikan batasan untuk diakses oleh orang lain atau dalam waktu tertentu, (c) kompatibilitas merupakan layanan seluler yang disesuaikan dengan kebutuhan pengguna, dan (d) kenyamanan, hal ini merupakan kemampuan seseorang mempercayai sebuat manfaat teknologi.

Di sisi lain, Kim (2010) juga menyatakan bahwa mobile payment memiliki beberapa karakteristik yaitu mobility, reachability, compatibility, dan convenience. Pertama, mobility merupakan kemampuan untuk mengakses layanan di mana-mana, saat bepergian, dan melalui jaringan nirkabel dan berbagai perangkat seluler, termasuk ponsel. Kedua, reachability yaitu kemampuan yang memungkinkan seseorang untuk dihubungi kapan saja dan di mana saja oleh layanan tersebut, serta menyediakan pengguna dengan pilihan untuk membatasi jangkauan mereka ke orang atau waktu tertentu. Ketiga, compatibility yaitu layanan seluler yang sesuai dengan kebutuhan pengguna serta gaya hidup, dan memungkinkan pengguna mencoba layanan baru yang memiliki pengaruh positif pada sikap terhadap penggunaan teknologi seluler. Terakhir, convenience merupakan kemampuan yang memungkinkan seseorang sangat percaya pada manfaat teknologi, tetapi hanya ketika teknologi didasarkan pada niat pengguna untuk membuat lebih mudah digunakan bagi seseorang dan untuk memperbaiki kesulitan dalam penggunaan.

\section{Mobile Payment Knowledge}

Menurut Kim (2010:313), “mobile payment knowledge merupakan pengetahuan yang dimiliki oleh pengguna terkait penggunaan mobile payment dalam beberapa layanan dan pengguna berani mau mencoba lebih banyak layanan baru." Mobile payment knowledge ini sangat penting bagi pengguna untuk mengetahui 
seberapa mudah pengguna untuk menggunakan mobile payment yang menawarkan layanan kepada mereka.

\section{Technology Acceptance Model (TAM)}

Davis (1989) mengungkapkan bahwa technology acceptance model (TAM) merupakan sebuah "model yang menjelaskan penggunaan sistem teknologi informasi yang dianggap sangat berpengaruh dan umumnya digunakan untuk menjelaskan penerimaan individual terhadap penggunaan sistem teknologi informasi”. Di sisi lain, Nasri (2012), TAM merupakan salah satu kerangka teoritis untuk memprediksi penerimaan dan penggunaan teknologi informasi baru (perangkat lunak dan sistem informasi) dalam organisasi. Sementara itu, Kesharwani (2011) menyatakan bahwa model penerimaan teknologi dianggap model yang paling banyak digunakan dan kuat untuk memprediksi individu terkait dengan adopsi teknologi baru.

Model dari TAM dapat dilihat pada gambar berikut:

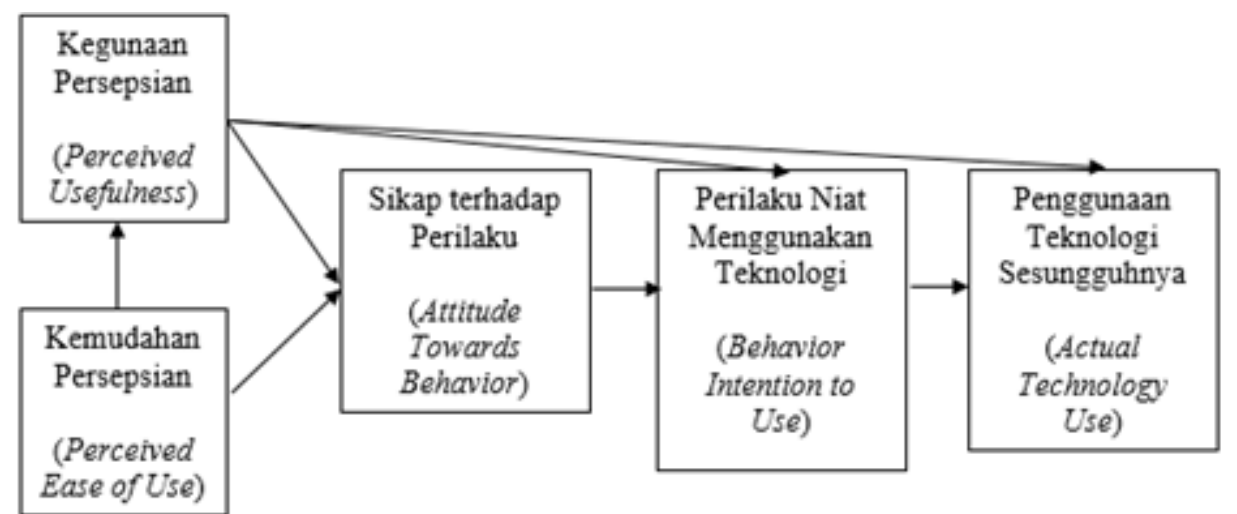

Gambar 1 Technology Acceptance Model (TAM)

Sumber: Jogiyanto (2007)

\section{Kepercayaan (Perceived Trust)}

Gefen et al. (2003) mengungkapkan bahwa "kepercayaan adalah aspek sentral dalam banyak transaksi ekonomi karena kebutuhan manusia yang mendalam untuk memahami lingkungan sosial, yaitu seperti mengidentifikasi apa, kapan, mengapa, dan bagaimana orang lain berperilaku". Sementara itu, Marakarkandy (2017) mengungkapkan bahwa "kepercayaan adalah konsep yang menggabungkan perilaku dengan keputusan seseorang berdasarkan pendapat orang yang dapat 
diandalkan dan menumbuhkan harapan bagi pengguna”. Dengan demikian, kepercayaan berkaitan dengan ketidakpastian lingkungan dan kepuasan pelanggan.

\section{Keamanan dan Privasi (Perceived Security and Privacy)}

Gefen et al. (2003) mengungkapkan bahwa "keamanan adalah perasaan khawatir seseorang mengenai masalah dalam menggunakan layanan dan melakukan transaksi, terutama pada layanan baru." Perasaan ini terdapat pada kemudahan penggunaan dan kegunaan yang dirasakan ketika mereka memiliki niat untuk menggunakan layanan baru. Sementara itu, Keamanan informasi pelanggan menurut Liu et al. (2015) sangat penting bagi semua bisnis untuk melayani klien karena pelanggan harus aman ketika melakukan pembelian dan menunggu penyelesaian transaksi tanpa khawatir. Oleh karena itu, keamanan yang dirasakan dapat meningkatkan jumlah pelanggan untuk melakukan transaksi dalam lingkungan online. Ketika pengguna mempercayai keamanan layanan, mereka akan dengan nyaman menikmati manfaat yang diberikan oleh layanan tersebut.

\section{Kerangka Pemikiran}

Keputusan individu untuk menggunakan suatu teknologi informasi merupakan tindakan yang dapat diprediksi melalui karakteristik, pengetahuan individu, serta model penerimaan terhadap penggunaan mobile payment. Apabila pengguna memiliki pengetahuan terhadap penggunaan mobile payment, maka pengguna lebih berani untuk mencoba mobile payment OVO pada Grab. Di sisi lain, pengguna akan tertarik menggunakan mobile payment OVO jika memiliki karakteristik dapat digunakan dimana saja (mobility), pengguna dapat dihubungi kapan saja (reachability), pengguna dapat mencoba layanan baru dan memiliki pengaruh positif terhadap penggunaan mobile payment (compatibility), dan pengguna merasa nyaman menggunakan mobile payment (convenience).

Teknologi mobile payment yang berguna (perceived usefulness) dan mudah digunakan (perceived ease of use) akan memberikan dampak pada minat dan perilaku pengguna dalam menggunakan mobile payment untuk melakukan transaksi pembayaran. Penggunaan teknologi juga akan memberikan rasa percaya (perceived trust) kepada pengguna yang dapat mengubah minat dan perilaku individu. Jika 
seseorang percaya dalam menggunakan mobile payment, maka pengguna akan merasakan keamanan dan privasi (perceived security and privacy) yang didapat ketika menggunakan mobile payment sebagai alat pembayaran.

Berdasarkan penelitian terdahulu oleh Gilang (2017), kualitas pelayanan berpengaruh terhadap kepuasan pelanggan jasa taksi berbasis online (GrabCar). Hasil yang didapat dalam penelitian ini mengenai penilaian kualitas pelayanan GrabCar terhadap ketepatan waktu penyampaian pesanan, pemberitahuan apabila terjadi keterlambatan, dan mengemudikan mobil sesuai dengan peraturan lalu lintas. Penelitian ini berbeda dengan penelitian terdahulu yang dilakukan oleh Gilang karena penelitian ini bertujuan untuk melakukan analisis mengenai persepsi penerimaan dan penggunaan mobile payment OVO terhadap pengguna Grab. Beberapa kajian Pustaka yang digunakan pada penelitian ini adalah model TAM yang mengacu pada Jogiyanto (2007) sesuai dengan model yang dikemukakan oleh Davis et. al (1989) dan peneliti menambahkan variabel eksternal yang berada di luar kotak TAM mengenai perceived trust yang mengacu pada Marakarkandy (2017), Gefen et. al (2003), dan Kesharwani (2011), perceived security and privacy yang mengacu pada Nasri (2012), mobile payment characteristic dan mobile payment knowledge yang mengacu pada Kim (2010).

Adapun model yang diusulkan dalam penelitian ini sebagai berikut:

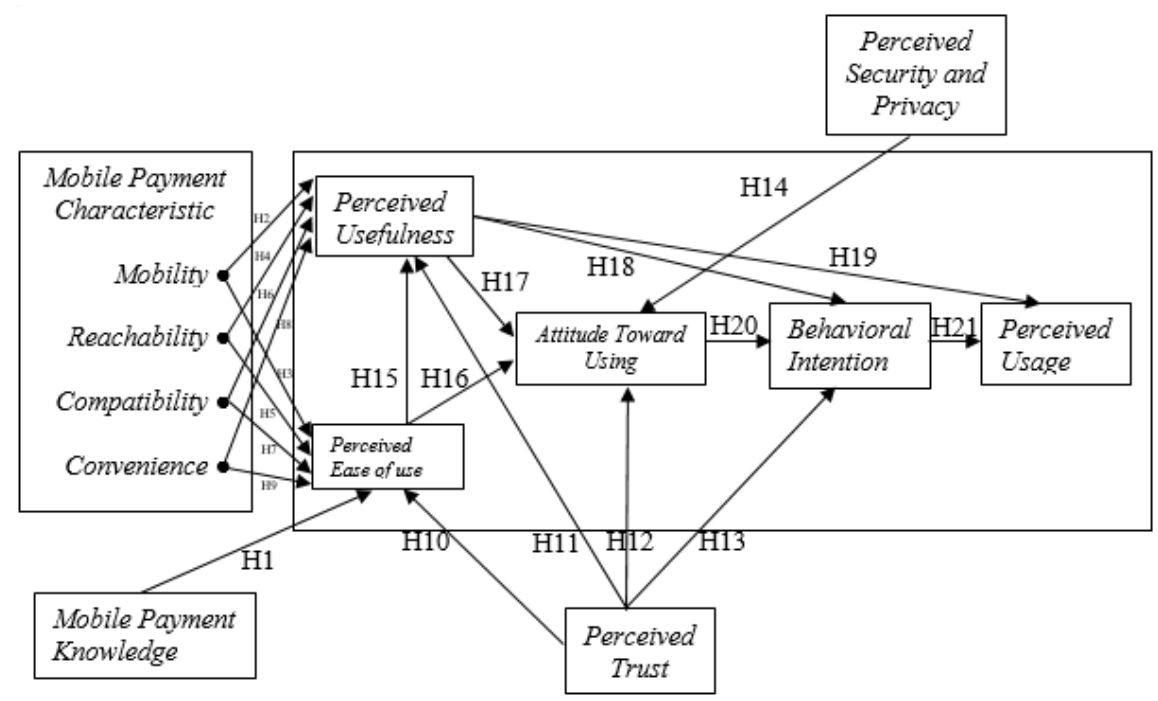

Gambar 2

Model penelitian yang diusulkan dalam penelitian ini (2019) 


\section{Rumusan Hipotesis}

\section{Pengaruh Mobile Payment Knowledge terhadap Perceived Ease of Use}

Menurut Kim (2010), pengetahuan penggunaan mobile payment sangat penting mengingat popularitas ponsel saat ini sudah mulai berkembang. Pengetahuan menjadi penting bagi pengguna karena pengguna dapat mencoba layanan baru dan menggunakan mobile payment sebagai metode pembayarannya. Selanjutnya penelitian Davis (1989), mengungkapkan bahwa kemudahan penggunaan persepsian (perceived ease of use) adalah sejauh mana seseorang merasa mudah dalam menggunakan suatu teknologi dan kemudahan tersebut dapat memberikan keringanan terhadap tanggung jawab seeorang.

Pengguna mobile payment OVO pada transportasi online Grab dengan pengetahuan tingkat tinggi terkait dengan pembayaran cenderung akan lebih mudah menggunakan sistem pembayaran tersebut, dibandingkan dengan pengguna yang kurang memiliki pengetahuan tersebut. Pernyataan ini didukung oleh penelitian Kim (2010) yang menyatakan bahwa mobile payment knowledge memiliki pengaruh signifikan terhadap perceived ease of use. Hal ini dapat dijelaskan bahwa pengetahuan tentang m-payment memberikan awal kepercayaan diri untuk mencoba fitur pembayaran dalam konteks penggunaan. Apabila seseorang memiliki pengetahuan dalam menggunakan OVO pada layanan transportasi Grab, maka pengguna akan merasa lebih mudah untuk menggunakan dibandingkan yang tidak memiliki pengetahuan. Dengan demikian, rumusan hipotesis dalam penelitian ini sebagai berikut:

H1 : Mobile Payment Knowledge berpengaruh terhadap Perceived Ease of Use.

\section{Pengaruh Mobility terhadap Perceived Usefulness}

Menurut Kim (2010:313), mobilitas adalah kondisi pengguna dapat mengakses layanan dimana saja dan kapan saja dengan menggunakan ponsel dan jaringan nirkabel untuk melakukan transaksi. Sementara itu, penelitian Davis (1989) mendefinisikan kegunaan persepsian (perceived usefulness) sebagai sejauh mana seseorang percaya bahwa menggunakan suatu teknologi akan memberikan manfaat kepada pengguna.

Dalam penelitian Kim (2010) menyatakan bahwa mobility memiliki pengaruh signifikan terhadap perceived usefulness. Hal ini dijelaskan bahwa 
pengguna seluler membutuhkan akses untuk mendapatkan informasi, komunikasi, dan jasa dimana saja dan kapan saja. Apabila mobile payment OVO dapat digunakan dalam layanan Grab dimana saja dan kapan saja, maka pengguna percaya bahwa teknologi tersebut akan memberikan manfaat. Dengan demikian, rumusan hipotesis dalam penelitian ini sebagai berikut:

H2 : Mobility berpengaruh terhadap Perceived Usefulness

\section{Pengaruh Mobility terhadap Perceived Ease of Use}

Menurut Kim (2010:313), mobilitas adalah pengguna dapat mengakses layanan dimana saja dan kapan saja dengan menggunakan ponsel dan jaringan nirkabel untuk melakukan transaksi. Selanjutnya Davis (1989) mengungkapkan bahwa kemudahan penggunaan persepsian (perceived ease of use) adalah persepsi yang dimiliki seseorang ketika teknologi yang digunakan tersebut mudah sehingga memberikan keringanan bagi dirinya.

Dalam penelitian Kim (2010) menyatakan bahwa mobility memiliki pengaruh yang tidak signifikan terhadap perceived ease of use. Hal ini dijelaskan bahwa terdapat perbedaan antara dua kelompok pengguna pemula dan pengguna lama yang memberikan tanggapan mereka terhadap mobilitas mengenai akses pemberian informasi. Apabila seseorang dapat menggunakan OVO pada Grab dimana saja, maka pengguna dapat mengakses layanan dengan mudah. Dengan demikian, rumusan hipotesis dalam penelitian ini sebagai berikut:

H3 : Mobility berpengaruh terhadap Perceived Ease of Use

\section{Pengaruh Reachability terhadap Perceived Usefulness}

Menurut Kim (2010:313-314), reachability yaitu seseorang yang dapat dihubungi kapan saja dan dimana saja oleh layanan tersebut. Selanjutnya penelitian Davis (1989), kegunaan persepsian (perceived usefulness) didefinisikan sebagai sejauh mana seseorang percaya bahwa menggunakan suatu teknologi akan memberikan manfaat kepada pengguna.

Pengguna mobile payment OVO pada transportasi Grab akan mudah untuk dihubungi kapan saja dan dimana saja dalam layanan tersebut dan memberikan banyak manfaat dalam melakukan transaksi. Pernyataan ini didukung oleh penelitian Kim (2010) yang menyatakan bahwa reachability memiliki pengaruh signifikan terhadap perceived usefulness. Hal ini dijelaskan bahwa pengguna akan mudah untuk 
dihubungi kapan saja untuk berbagai situasi. Apabila seseorang menggunakan OVO pada Grab dan dapat dihubungi kapan saja oleh pihak Grab, maka pengguna percaya dalam penggunaan aplikasi tersebut akan memberikan manfaat. Dengan demikian, rumusan hipotesis dalam penelitian ini sebagai berikut:

H4 : Reachability berpengaruh terhadap Perceived Usefulness

\section{Pengaruh Reachability terhadap Perceived Ease of Use}

Menurut Kim (2010:313-314), reachability yaitu seseorang dapat dihubungi kapan saja dan dimana saja oleh layanan tersebut. Berdasarkan penelitian Davis (1989), kemudahan penggunaan persepsian (perceived ease of use) didefinisikan sebagai sejauh mana seseorang merasa mudah dalam menggunakan suatu teknologi dan kemudahan tersebut dapat memberikan keringanan terhadap tanggung jawab seseorang.

Berdasarkan penelitian oleh Kim (2010), reachability memiliki pengaruh signifikan terhadap perceived ease of use. Hal ini dijelaskan bahwa penyedia layanan dapat menjangkau pengguna untuk memberitahu mereka mengenai transaksi baru. Apabila seseorang menggunakan perangkat OVO pada Grab dan dapat dihubungi kapan saja oleh pihak Grab, maka pengguna merasa mudah dalam menggunakan layanan Grab dengan menggunakan OVO. Dengan demikian, rumusan hipotesis dalam penelitian ini sebagai berikut:

H5: Reachability berpengaruh terhadap Perceived Ease of Use

\section{Pengaruh Compatibility terhadap Perceived Usefulness}

Menurut Kim (2010:314), kompatibilitas yaitu seseorang yang mencoba layanan baru sesuai dengan kebutuhan pengguna saat menggunakan layanan tersebut. Selanjutnya penelitian Davis (1989) mengatakan bahwa kegunaan persepsian (perceived usefulness) adalah sejauh mana seseorang percaya bahwa menggunakan suatu teknologi akan memberikan manfaat kepada pengguna.

Dalam penelitian Kim (2010), compatibility memiliki pengaruh yang tidak signifikan terhadap perceived usefulness. Hal ini dijelaskan bahwa layanan tidak memberikan kesesuaian terhadap kemauan pengguna. Apabila seseorang memungkinkan mencoba layanan baru dengan menggunakan OVO pada Grab, maka pengguna percaya bahwa menggunakan aplikasi tersebut akan memberikan manfaat. Dengan demikian, rumusan hipotesis dalam penelitian ini sebagai berikut: 
H6 : Compatibility berpengaruh terhadap Perceived Usefulness

\section{Pengaruh Compatibility terhadap Perceived Ease of Use}

Menurut Kim (2010:314), kompatibilitas yaitu seseorang yang mencoba layanan baru sesuai dengan kebutuhan pengguna dengan menggunakan layanan tersebut. Selanjutnya penelitian Davis (1989) menyatakan bahwa kemudahan penggunaan persepsian (perceived ease of use) didefinisikan sebagai sejauh mana seseorang merasa mudah dalam menggunakan suatu teknologi dan kemudahan tersebut dapat memberikan keringanan terhadap tanggung jawab seeorang.

Dalam penelitian Kim (2010) menyatakan bahwa compatibility memiliki pengaruh yang tidak signifikan terhadap perceived ease of use. Hal ini dijelaskan bahwa layanan tidak memberikan kemudahan kepada pengguna saat akan melakukan transaksi. Apabila seseorang memungkinkan mencoba layanan baru dengan menggunakan OVO pada Grab, maka pengguna dengan mudah menggunakan aplikasi tersebut. Dengan demikian, rumusan hipotesis dalam penelitian ini sebagai berikut:

H7: Compatibility berpengaruh terhadap Perceived Ease of Use

\section{Pengaruh Convenience terhadap Perceived Usefulness}

Menurut Kim (2010:314), kenyamanan (convenience) merupakan salah satu faktor yang dirasa pengguna dan menyangkut pada perilaku pengguna dalam menggunakan suatu teknologi. Berdasarkan penelitian Davis (1989), kegunaan persepsian (perceived usefulness) didefinisikan sebagai sejauh mana seseorang percaya bahwa menggunakan suatu teknologi akan memberikan manfaat kepada pengguna.

Dalam penelitian Kim (2010) menyatakan bahwa convenience memiliki pengaruh signifikan terhadap perceived usefulness. Hal ini dijelaskan bahwa layanan dapat menghasilkan kenyamanan waktu dan tempat serta fasilitas untuk pengguna. Apabila seseorang nyaman menggunakan OVO pada Grab, maka pengguna percaya bahwa menggunakan aplikasi tersebut akan memberikan manfaat. Dengan demikian, rumusan hipotesis dalam penelitian ini sebagai berikut:

H8 : Convenience berpengaruh terhadap Perceived Usefulness 


\section{Pengaruh Convenience terhadap dan Perceived Ease of Use}

Menurut Kim (2010:314), kenyamanan (convenience) merupakan salah satu faktor yang dirasakan oleh pengguna dan menyangkut pada perilaku pengguna dalam menggunakan suatu teknologi. Sementara itu, penelitian Davis (1989) mendefinisikan kemudahan penggunaan persepsian (perceived ease of use) sebagai sejauh mana seseorang merasa mudah dalam menggunakan suatu teknologi dan kemudahan tersebut dapat memberikan keringanan terhadap tanggung jawab seeorang.

Dalam penelitian Kim (2010) menyatakan bahwa convenience memiliki pengaruh signifikan terhadap perceived ease of use. Hal ini menjelaskan bahwa ketersediaan alternatif dalam penggunaan layanan membuat pengguna menggunakan layanan tersebut. Apabila seseorang nyaman menggunakan OVO pada Grab, maka pengguna dapat dengan mudah menggunakan aplikasi tersebut. Dengan demikian, rumusan hipotesis dalam penelitian ini sebagai berikut:

H9 : Convenience berpengaruh terhadap Perceived Ease of Use

\section{Pengaruh Perceived Trust terhadap Perceived Ease of Use}

Menurut Marakarkandy et al. (2017:269) mendefinisikan kepercayaan sebagai harapan seseorang yang dipegang teguh dan dapat dipercaya saat menggunakan suatu teknologi. Selain itu, penelitian Davis (1989) mendefinisikan kemudahan penggunaan persepsian (perceived ease of use) sebagai sejauh mana seseorang merasa mudah dalam menggunakan suatu teknologi dan kemudahan tersebut dapat memberikan keringanan terhadap tanggung jawab seeorang.

Dalam penelitian Marakarkandy (2017) menyatakan bahwa perceived trust memiliki pengaruh yang tidak signifikan terhadap perceived ease of use. Hal ini dijelaskan bahwa kepercayaan konsumen berkurang berkaitan dengan ketidakpastian lingkungan sehingga konsumen tidak merasa mudah untuk menggunakannya. Apabila seseorang percaya akan penggunaan OVO pada Grab, maka akan muncul kemudahan penggunaan seseorang dalam menggunakan aplikasi sebab aplikasi ini memberikan manfaat. Dengan demikian, rumusan hipotesis dalam penelitian ini sebagai berikut:

H10 : Kepercayaan (Perceived Trust) berpengaruh terhadap kemudahan penggunaan persepsian (Perceived Ease of Use). 


\section{Pengaruh Perceived Trust terhadap Perceived Usefulness}

Menurut Marakarkandy et al (2017:269) mendefinisikan kepercayaan sebagai harapan seseorang yang dipegang teguh dan dapat dipercaya saat menggunakan suatu teknologi. Selain itu, penelitian Davis (1989) mendefinisikan kegunaan persepsian (perceived usefulness) sebagai sejauh mana seseorang percaya bahwa menggunakan suatu teknologi akan memberikan manfaat kepada pengguna.

Dalam penelitian Marakarkandy (2017) menyatakan bahwa perceived trust memiliki pengaruh yang tidak signifikan terhadap perceived usefulness. Hal ini dijelaskan apabila kondisi lingkungan dan reputasi dari layanan tersebut memberikan pengaruh yang tidak baik, maka konsumen akan enggan dan sulit untuk mencoba suatu layanan. Apabila seseorang percaya akan penggunaan OVO pada Grab, maka akan muncul penggunaan seseorang dalam menggunakan aplikasi tersebut. Dengan demikian, rumusan hipotesis dalam penelitian ini sebagai berikut:

H11 : Kepercayaan (Perceived Trust) berpengaruh terhadap kegunaan persepsian (Perceived Usefulness).

\section{Pengaruh Perceived Trust terhadap Attitude Towards Using}

Menurut Marakarkandy et al (2017:269) mendefinisikan kepercayaan sebagai harapan seseorang yang dipegang teguh dan dapat dipercaya saat menggunakan suatu teknologi. Selanjutnya, sikap terhadap perilaku (attitude towards using) didefinisikan oleh Davis et. al (1989) sebagai perasaan seseorang dalam bentuk perasaan positif atau negatif jika melakukan perilaku yang akan ditentukan.

Dalam penelitian Marakarkandy (2017) menyatakan bahwa perceived trust memiliki pengaruh yang tidak signifikan terhadap attitude towards using. Hal ini dijelaskan apabila konsumen menerima pelayanan yang buruk sehingga konsumen akan menggunakan layanan dengan sikap yang tidak baik bahkan tidak akan menggunakan layanan tersebut lagi akibat konsumen tidak merasa percaya lagi. Apabila seseorang percaya akan penggunaan OVO pada Grab, maka akan muncul sikap terhadap perilaku seseorang dalam menggunakan aplikasi tersebut. Dengan demikian, rumusan hipotesis dalam penelitian ini sebagai berikut:

H12 : Kepercayaan (Perceived Trust) berpengaruh terhadap sikap pada perilaku (Attitude Towards Using). 


\section{Pengaruh Perceived Trust terhadap Behavioral Intention}

Menurut Marakarkandy et al (2017:269) mendefinisikan kepercayaan sebagai harapan seseorang yang dipegang teguh dan dapat dipercaya saat menggunakan suatu teknologi. Selain itu, Jogiyanto (2007) mengatakan bahwa minat perilaku (behavioral intention) didefinisikan sebagai keinginan seseorang untuk melakukan sesuatu sesuai dengan perilaku tertentu.

Dalam penelitian Marakarkandy (2017) menyatakan bahwa perceived trust memiliki pengaruh yang tidak signifikan terhadap behavioral intention. Hal ini dijelaskan bahwa tingkat kepercayaan pengguna berkurang akibat kepuasan pengguna yang tidak dapat diberikan dengan baik sehingga minat pengguna akan berkurang. Apabila seseorang percaya akan penggunaan OVO pada Grab, maka akan muncul minat seseorang dalam menggunakan aplikasi tersebut. Dengan demikian, rumusan hipotesis dalam penelitian ini sebagai berikut:

H13 : Kepercayaan (Perceived Trust) berpengaruh terhadap Minat Perilaku (Behavioral Intention).

\section{Pengaruh Perceived Security and Privacy terhadap Attitude Towards Using}

Menurut Nasri (2012:4-5) mengungkapkan bahwa keamanan dan privasi merupakan perasaan seseorang ketika akan menggunakan suatu teknologi dan layanan baru, dimana seseorang memberikan data pribadi untuk melakukan suatu transaksi. Sikap terhadap perilaku (attitude towards using) didefinisikan oleh Davis et. al (1989) sebagai perasaan seseorang dalam bentuk perasaan positif atau negatif jika melakukan perilaku yang akan ditentukan.

Dalam penelitian Nasri (2012) menyatakan bahwa perceived security and privacy memiliki pengaruh signifikan terhadap attitude towards using. Hal ini dijelaskan pengguna aktif menggunakan internet banking dan pengguna sadar bahwa sistem yang mereka gunakan dapat dijamin keamanan informasi pribadinya serta keuangan konsumen juga dilindungi. Apabila seseorang merasa aman dan terjaga privasinya saat menggunakan OVO pada Grab, maka seseorang akan menunjukkan sikap dalam menggunakan suatu aplikasi tersebut. Dengan demikian, rumusan hipotesis dalam penelitian ini sebagai berikut:

H14 : Keamanan dan Privasi (Perceived Security and Privacy) berpengaruh terhadap sikap pada perilaku (Attitude Towards Using. 


\section{Pengaruh Perceived Ease of Use terhadap Perceived Usefulness}

Menurut Davis (1989), kemudahan penggunaan persepsian (perceived ease of use) didefinisikan sebagai sejauh mana seseorang merasa mudah dalam menggunakan suatu teknologi dan kemudahan tersebut dapat memberikan keringanan terhadap tanggung jawab seeorang. Kegunaan persepsian (perceived usefulness) didefinisikan sebagai sejauh mana seseorang percaya bahwa menggunakan suatu teknologi akan memberikan manfaat kepada pengguna.

Dalam penelitian Kim (2010) menyatakan bahwa perceived ease of use memiliki pengaruh signifikan terhadap perceived usefulness. Hal ini dijelaskan bahwa layanan mencegah penggunaan sistem m-payment yang kurang dimanfaatkan dengan cara memberikan kemudahan dan mudah dipelajari. Apabila seseorang dengan mudah menggunakan OVO pada Grab, maka seseorang akan menggunakan aplikasi tersebut secara terus menerus. Berdasarkan penelitian sebelumnya dari Davis (1989), penelitian tersebut menunjukkan bahwa konstruk kemudahan penggunaan persepsian (perceived ease of use) mempengaruhi kegunaan persepsian (perceived usefulness).

H15 : Perceived Ease of Use berpengaruh terhadap Perceived Usefulness.

\section{Pengaruh Perceived Ease of Use terhadap Attitude Towards Using}

Menurut Davis (1989), kemudahan penggunaan persepsian (perceived ease of use) didefinisikan sebagai sejauh mana seseorang merasa mudah dalam menggunakan suatu teknologi dan kemudahan tersebut dapat memberikan keringanan terhadap tanggung jawab seeorang. Sikap terhadap perilaku (attitude towards using) didefinisikan sebagai perasaan seseorang dalam bentuk perasaan positif atau negatif jika melakukan perilaku yang akan ditentukan.

Dalam penelitian Nasri (2012) menyatakan bahwa perceived ease of use memiliki pengaruh signifikan terhadap attitude towards using. Hal ini dijelaskan bahwa survei barang untuk kegunaan yang dirasakan, sikap, dan niat yang digunakan untuk menggunakan internet banking dapat memberikan pengaruh yang besar terhadap kemudahan. Apabila seseorang percaya menggunakan OVO pada Grab dapat memberikan kemudahan, maka menimbulkan sikap positif atau negatif terhadap penggunaanya. Oleh sebab itu, kemudahan penggunaan persepsian 
(perceived ease of use) mempengaruhi sikap terhadap perilaku (attitude towards using).

H16 : Perceived Ease of Use berpengaruh terhadap Attitude Towards Using.

\section{Pengaruh Perceived Usefulness terhadap Attitude Towards Using}

Menurut Davis (1989), kegunaan persepsian (perceived usefulness) didefinisikan sebagai sejauh mana seseorang percaya bahwa menggunakan suatu teknologi akan memberikan manfaat kepada pengguna. Sikap terhadap perilaku (attitude towards using) didefinisikan sebagai perasaan seseorang dalam bentuk perasaan positif atau negatif jika melakukan perilaku yang akan ditentukan.

Dalam penelitian Nasri (2012) menyatakan bahwa perceived usefulness memiliki pengaruh signifikan terhadap attitude towards using. Hal ini dijelaskan bahwa kegunaan menunjukkan sikap pengguna terutama dalam memperoleh keuntungan dari perbankan online. Apabila seseorang merasa menggunakan OVO pada Grab akan bermanfaat bagi dirinya, maka hal ini akan menimbulkan sikap positif terhadap penggunanya. Dengan demikian, rumusan hipotesis dalam penelitian ini sebagai berikut:

H17 : Perceived Usefulness berpengaruh terhadap Attitude Towards Using.

\section{Pengaruh Perceived Usefulness terhadap Behavioral Intention}

Menurut Davis (1989), kegunaan persepsian (perceived usefulness) didefinisikan sebagai sejauh mana seseorang percaya bahwa menggunakan suatu teknologi akan memberikan manfaat kepada pengguna. Selain itu, Jogiyanto mengatakan bahwa minat perilaku (behavioral intention) didefinisikan sebagai keinginan seseorang untuk melakukan sesuatu sesuai dengan perilaku tertentu.

Dalam penelitian Hwang (2003) menyatakan bahwa perceived usfulness memiliki pengaruh signifikan terhadap behavioral intention. Hal ini dijelaskan bahwa asumsi semua pengguna sama dan pengguna mempertimbangkan sistem yang lebih berguna ketika membuat pengguna menikmati keuntungan. Seseorang akan menggunakan OVO pada Grab apabila memberikan manfaat sehingga mendorong minat untuk menggunakannya. Berdasarkan penelitian sebelumnya dari Davis (1989), kegunaan persepsian (perceived usefulness) mempengaruhi secara positif dan signifikan terhadap minat (behavioral intention). Dengan demikian, rumusan hipotesis dalam penelitian ini sebagai berikut: 
H18 : Perceived Usefulness berpengaruh terhadap Behavioral Intention.

\section{Pengaruh Perceived Usefulness terhadap Perceived Usage}

Menurut Davis (1989), kegunaan persepsian (perceived usefulness) didefinisikan sebagai sejauh mana seseorang percaya bahwa menggunakan suatu teknologi akan memberikan manfaat kepada pengguna. Selain itu, penelitian Igbaria et al. (1995) mendefinisikan penggunaan persepsian sebagai pengukuran pada jumlah waktu seseorang saat menggunakan suatu teknologi.

Penelitian sebelumnya pada Davis (1989) menunjukkan bahwa konstruk kegunaan persepsian (perceived usefulness) mempengaruhi secara positif dan signifikan terhadap penggunaan sistem informasi (perceived usage). Hal ini dijelaskan bahwa pengguna menggunakan aplikasi sesering mereka menggunakan handphone mereka dan dapat dihitung seberapa sering mereka menggunakannya. Semakin orang percaya dalam menggunakan OVO pada Grab, maka jumlah waktu akan interaksi penggunaan aplikasi tersebut juga akan sering. Dengan demikian, rumusan hipotesis dalam penelitian ini sebagai berikut:

H19 : Perceived Usefulness berpengaruh terhadap Perceived Usage.

\section{Pengaruh Attitude Towards Using terhadap Behavioral Intention}

Menurut Davis (1989), sikap terhadap perilaku (attitude towards using) didefinisikan sebagai perasaan seseorang dalam bentuk perasaan positif atau negatif jika melakukan perilaku yang akan ditentukan. Selain itu, Jogiyanto (2007) mengatakan bahwa minat perilaku (behavioral intention) didefinisikan sebagai keinginan seseorang untuk melakukan sesuatu sesuai dengan perilaku tertentu.

Dalam penelitian Nasri (2012) menyatakan bahwa attitude towards using memiliki pengaruh signifikan terhadap behavioral intention. Hal ini dijelaskan bahwa sikap sosial seseorang terhadap penggunaan layanan bank akan meningkatkan minat belanja. Seseorang akan memberikan sikap positif maupun negatif terhadap penggunaan OVO pada Grab jika mempunyai keinginan atau minat untuk melakukannya. Dengan demikian, rumusan hipotesis dalam penelitian ini sebagai berikut:

H20 : Attitude Towards Using berpengaruh terhadap Behavioral Intention 


\section{Pengaruh Behavioral Intention terhadap Perceived Usage}

Menurut Jogiyanto (2007), minat perilaku (behavioral intention) didefinisikan sebagai keinginan seseorang untuk melakukan sesuatu sesuai dengan perilaku tertentu. Selain itu, penelitian Igbaria et al. (1995) mendefiniskan penggunaan persepsian sebagai pengukuran pada jumlah waktu seseorang saat menggunakan suatu teknologi.

Dalam penelitian Marakarkandy (2017) mengatakan bahwa behavioral intention memiliki pengaruh signifikan terhadap perceived usage. Hal ini dijelaskan jika pengguna terlibat dalam transaksi dengan perbankan, maka dalam waktu dekat pengguna akan menggunakan internet banking dan internet yang mendukungnya. Apabila seseorang mempunyai minat untuk menggunakan OVO pada Grab, maka waktu yang digunakan untuk berinteraksi dengan aplikasi tersebut akan rutin. Dengan demikian, rumusan hipotesis dalam penelitian ini sebagai berikut:

H21 : Behavioral Intention berpengaruh terhadap Perceived Usage

\section{Metode Penelitian}

Penelitian ini merupakan penelitian kuantitatif dengan menggunakan pendekatan survei. Menurut Sekaran (2016:97), survei adalah sebuah sistem untuk mengumpulkan berbagai informasi dari seseorang guna untuk menggambarkan, membandingkan, ataupun menjelaskan suatu pengetahuan, sikap, dan perilaku mereka. Survei dalam penelitian ini ditujukan kepada responden sebagai pengguna aplikasi transportasi Grab yang menggunakan OVO sebagai metode alat pembayarannya. Adapun kriteria Penelitian ini mengambil responden pengguna OVO saat bertransaksi melalui aplikasi transportasi Grab yang tersebar di wilayah JaBoTaBek dan Daerah Istimewa Yogyakarta. Survei dikirimkan lewat komputer ini dengan menggunakan internet untuk menyebarkan pertanyaan-pertanyaan (kuesioner), lalu kemudian disebarkan dalam grup-grup diskusi yang relevan dengan membantu survei yang digunakan. Penyebaran ini bisa melalui e-mail atau dapat lewat situs jaringan (web site) (Jogiyanto, 2017:143).

Selain itu, Populasi dalam penelitian ini adalah pengguna OVO grab pada transportasi online Grab yang berada di wilayah Jabodetabek dan Yogyakarta. Dengan demikian, teknik pengambilan sampel yaitu snowball sampling. Teknik ini 
adalah teknik penentuan sampel yang mula-mula jumlahnya kecil, kemudian semakin membesar (Sugiyono, 2017:145). Peneliti menggunakan link google form sebagai alat untuk penyebaran kuesioner secara online. Kuesioner disusun dengan menggunakan skala likert 1-4. Penelitian ini menghilangkan indikator 'Netral' dan menggunakan skala likert genap karena alasan tidak digunakannya indikator tersebut agar responden menyatakan persetujuan atau pertidaksetujuannya atas pernyataan yang disampaikan kepadanya (Santosa; 2008:46-47).

Selanjutnya, penelitian ini menggunakan teknik analisis data yaitu analisis jalur dengan menggunakan alat statistik SmartPLS versi 3.2. Menurut Abdillah dan Jogiyanto (2015:164), "PLS adalah analisis persamaan struktural (SEM) berbasis varian yang secara simultan dapat melakukan pengujian model pengukuran (outer model) sekaligus pengujian model struktural (inner model)". Model pengukuran dalam penelitian ini digunakan untuk uji validitas (konvergen dan diskriminan) dan reliabilitas. Sementara itu, model struktural digunakan untuk mengevaluasi $\mathrm{R}^{2}$ dan pengujian hipotesis.

\section{Hasil dan Pembahasan}

Pengumpulan data dalam penelitian ini dilakukan dengan penyebaran kuesioner online dan wawancara online kepada pengguna transportasi online Grab yang menggunakan OVO sebagai alat pembayaran. Data yang didapat sebanyak 228 responden yang berasal dari Jakarta, Bogor, Depok, Tangerang, Bekasi dan Yogyakarta. Dari 228 responden yang menjawab kuesioner online, semua kuesioner dapat diolah. Dari data yang diolah, dapat dilihat profil responden sebagai pengguna transportasi online Grab dengan menggunakan OVO sebagai alat pembayaran berdasarkan umur, domisili, status pekerjaan, pengalaman menggunakan sistem pembayaran OVO pada Grab, dan jumlah penggunaan penggunaan OVO pada transportasi online Grab. Tabel 1 menunjukkan informasi karakteristik responden.

\section{Analisis Data Penelitian}

\section{Pengujian Outer Model}

Dalam pengujian outer model digunakan untuk menguji validitas konvergen dan diskriminan. Pertama, pengujian validitas konvergen berhubungan dengan 
prinsip bahwa pengukur-pengukur dari suatu konstruk seharusnya berkorelasi tinggi (Abdillah dan Jogiyanto (2015:195). Pengujian dalam validitas konvergen digunakan untuk melakukan pengujian nilai outer loading dan nilai AVE (Average Variance Expected). Rule of thumb yang digunakan untuk validitas konvergen adalah outer loading lebih dari 0,7. Hasil uji validitas konvergen ditunjukkan dalam tabel 2.

Tabel 1. Karakteristik Responden

\begin{tabular}{|c|c|c|c|}
\hline Kriteria & Keterangan & $\begin{array}{l}\text { Jumlah } \\
\text { Responden }\end{array}$ & Presentase \\
\hline Pengalaman & Sudah & 228 & 99 \\
\hline Penggunaan & menggunakan & & \\
\hline \multirow[t]{3}{*}{ OVO } & Belum & 2 & 1 \\
\hline & Menggunakan & & \\
\hline & 1-3 kali & 67 & 30 \\
\hline Frekuensi & 4-6 kali & 28 & 12 \\
\hline \multirow{4}{*}{ Penggunaan } & kali & 9 & 4 \\
\hline & $>9$ kali & 124 & 54 \\
\hline & $15-19$ & 41 & 18 \\
\hline & $20-24$ & 167 & 73 \\
\hline \multirow[t]{5}{*}{ Usia } & $25-29$ & 9 & 4 \\
\hline & $>30$ & 11 & 5 \\
\hline & Jakarta & 39 & 17 \\
\hline & Bogor & 7 & 3 \\
\hline & Depok & 7 & 3 \\
\hline \multirow[t]{10}{*}{ Domisili } & Tangerang & 21 & 10 \\
\hline & Bekasi & 39 & 17 \\
\hline & Yogyakarta & 115 & 50 \\
\hline & Mahasiswa & 156 & 68 \\
\hline & $\begin{array}{c}\text { Pegawai (Swasta } \\
\text { dan Negeri) }\end{array}$ & 47 & 20 \\
\hline & Pelajar & 6 & 3 \\
\hline & Engineer & 1 & 0,4 \\
\hline & Staff & 2 & 1 \\
\hline & Auditor & 1 & 0,4 \\
\hline & Pengusaha & 1 & 0,4 \\
\hline Status & Buruh & 1 & 0,4 \\
\hline \multirow[t]{4}{*}{ Pekerjaan } & Wirausaha & 2 & 1 \\
\hline & Tenaga Pengajar & 6 & 3 \\
\hline & Musisi & 1 & 0,4 \\
\hline & Pengangguran & 4 & 2 \\
\hline
\end{tabular}

Sumber: Data diolah 2019. 
Tabel 2. Nilai Outer Loading

\begin{tabular}{|c|c|c|c|c|c|}
\hline Variabel & Indikator & Uji 1 & Keterangan & Uji 2 & Keterangan \\
\hline & MPK1 & 0,833 & VALID & 0,844 & VALID \\
\hline $\begin{array}{c}\text { Mobile } \\
\text { Payment }\end{array}$ & MPK2 & 0,655 & $\begin{array}{l}\text { TIDAK } \\
\text { VALID }\end{array}$ & - & - \\
\hline \multirow[t]{3}{*}{ Knowledge } & MPK3 & 0,862 & VALID & 0,880 & VALID \\
\hline & MPK4 & 0,814 & VALID & 0,819 & VALID \\
\hline & MOB1 & 0,854 & VALID & 0,854 & VALID \\
\hline \multirow[t]{3}{*}{ Mobility } & MOB2 & 0,874 & VALID & 0,874 & VALID \\
\hline & MOB3 & 0,866 & VALID & 0,866 & VALID \\
\hline & REA1 & 0,894 & VALID & 0,910 & VALID \\
\hline \multirow{3}{*}{ Reachability } & REA2 & 0,903 & VALID & 0,900 & VALID \\
\hline & REA3 & 0,259 & $\begin{array}{l}\text { TIDAK } \\
\text { VALID }\end{array}$ & - & - \\
\hline & COM1 & 0,833 & VALID & 0,833 & VALID \\
\hline \multirow{3}{*}{ Compatibility } & COM2 & 0,911 & VALID & 0,911 & VALID \\
\hline & COM3 & 0,830 & VALID & 0,830 & VALID \\
\hline & CON1 & 0,882 & VALID & 0,882 & VALID \\
\hline \multirow{4}{*}{ Convenience } & CON2 & 0,859 & VALID & 0,859 & VALID \\
\hline & CON3 & 0,828 & VALID & 0,828 & VALID \\
\hline & CON4 & 0,821 & VALID & 0,821 & VALID \\
\hline & PEOU1 & 0,879 & VALID & 0,879 & VALID \\
\hline Perceived & PEOU2 & 0,873 & VALID & 0,873 & VALID \\
\hline \multirow[t]{3}{*}{ Ease of Use } & PEOU3 & 0,887 & VALID & 0,887 & VALID \\
\hline & PEOU4 & 0,866 & VALID & 0,866 & VALID \\
\hline & PU1 & 0,815 & VALID & 0,815 & VALID \\
\hline \multirow{3}{*}{$\begin{array}{l}\text { Perceived } \\
\text { Usefulness }\end{array}$} & PU2 & 0,883 & VALID & 0,883 & VALID \\
\hline & PU3 & 0,819 & VALID & 0,819 & VALID \\
\hline & PU4 & 0,771 & VALID & 0,771 & VALID \\
\hline Attitude & ATU1 & 0,884 & VALID & 0,884 & VALID \\
\hline Towards & ATU2 & 0,865 & VALID & 0,865 & VALID \\
\hline Using & ATU3 & 0,753 & VALID & 0,753 & VALID \\
\hline \multirow{4}{*}{$\begin{array}{c}\text { Behavioral } \\
\text { Intention } \\
\text { Perceived } \\
\text { Usage }\end{array}$} & BIU1 & 0,930 & VALID & 0,930 & VALID \\
\hline & BIU2 & 0,911 & VALID & 0,911 & VALID \\
\hline & AU1 & 1,000 & VALID & 1,000 & VALID \\
\hline & TR1 & 0,92 & VALID & 0,92 & VALID \\
\hline \multirow{4}{*}{$\begin{array}{c}\text { Perceived } \\
\text { Trust }\end{array}$} & TR2 & 0,923 & VALID & 0,923 & VALID \\
\hline & TR3 & 0,806 & VALID & 0,806 & VALID \\
\hline & TR4 & 0,896 & VALID & 0,896 & VALID \\
\hline & SP1 & 0,855 & VALID & 0,855 & VALID \\
\hline \multirow{4}{*}{$\begin{array}{l}\text { Perceived } \\
\text { Security } \\
\text { and Privacy }\end{array}$} & SP2 & 0,796 & VALID & 0,796 & VALID \\
\hline & SP3 & 0,884 & VALID & 0,884 & VALID \\
\hline & SP4 & 0,854 & VALID & 0,854 & VALID \\
\hline & SP5 & 0,821 & VALID & 0,821 & VALID \\
\hline
\end{tabular}

Sumber: Data diolah 2019 
Dari informasi tabel 2, apabila nilai outer loading kurang dari rule of thumb yang ditetapkan untuk validitas konvergen yaitu outer loading lebih dari 0,7 maka, langkah selanjutnya adalah melakukan penghapusan terhadap nilai konstruk dibawah nilai rule of thumb tersebut dan melakukan pengujian kedua. Sehingga dapat disimpulkan bahwa, seluruh konstruk dalam penelitian ini sudah memiliki nilai outer loading yang memenuhi kriteria rule of thumb lebih dari 0,7 dan dapat dinyatakan valid. Di sisi lain, hal serupa juga sama dengan nilai AVE dimana nilai tersebut telah memenuhi nilai kriteria di atas 0,5. Berikut adalah informasi nilai AVE pada tabel 3.

\section{Tabel 3. Nilai AVE (Average Variance Expected)}

\begin{tabular}{lc}
\hline & $\begin{array}{c}\text { Average } \\
\text { Variance } \\
\text { Extracted } \\
(\text { AVE) }\end{array}$ \\
& \\
\hline Attitude Toward Using & 0.699 \\
Behavioral Intention & 0.847 \\
Compatibility & 0.738 \\
Convenience & 0.719 \\
Mobile Payment Knowledge & 0.719 \\
Mobility & 0.747 \\
Perceived Ease of Use & 0.768 \\
Perceived Security and Privacy & 0.710 \\
Perceived Trust & 0.788 \\
Perceived Usage & 1.000 \\
Perceived Usefulness & 0.677 \\
Reachability & 0.819 \\
\hline Sumber: Data diolah 2019
\end{tabular}

Sumber: Data diolah 2019

Kedua, validitas diskriminan berhubungan dengan prinsip bahwa pengukurpengukur konstruk yang berbeda seharusnya tidak berkorelasi dengan tinggi. Hasil uji validitas diskriminan ditampilkan dalam tabel 4 korelasi variabel laten.

\section{Uji Reliabilitas}

Uji reliabilitas dalam PLS dapat menggunakan dua metode, yaitu Cronbach's Alpha dan Composite Reliability. Cronbach's Alpha mengukur batas bawah nilai reliabilitas suatu konstruk, sedangkan Composite Reliability mengukur nilai sesungguhnya reliabilitas suatu konstruk. Suatu konstruk dikatakan reliabel jika nilai Cronbach's Alpha harus > 0,6 dan nilai Composite Reliability harus > 0,7. Dengan demikian, hasil dari uji reliabilitas pada tabel 5 menunjukkan nilai bahwa indikator kuesioner dalam penelitian ini telah memenuhi ketentuan dalam uji reliabilitas 
Tabel 4 korelasi variabel laten

\begin{tabular}{|c|c|c|c|c|c|c|c|c|c|c|c|c|}
\hline & ATU & BIU & COM & CON & MPK & МOB & PEOU & SP & TR & $\mathbf{A U}$ & PU & REA \\
\hline ATU & 0.836 & & & & & & & & & & & \\
\hline BIU & 0.700 & 0.920 & & & & & & & & & & \\
\hline COM & 0.778 & 0.641 & 0.859 & & & & & & & & & \\
\hline $\mathrm{CON}$ & 0.741 & 0.597 & 0.828 & 0.848 & & & & & & & & \\
\hline MPK & 0.557 & 0.511 & 0.589 & 0.571 & 0.848 & & & & & & & \\
\hline MOB & 0.647 & 0.645 & 0.746 & 0.739 & 0.496 & 0.865 & & & & & & \\
\hline PEOU & 0.694 & 0.531 & 0.671 & 0.688 & 0.472 & 0.598 & 0.876 & & & & & \\
\hline SP & 0.594 & 0.617 & 0.607 & 0.626 & 0.604 & 0.561 & 0.530 & 0.842 & & & & \\
\hline TR & 0.486 & 0.559 & 0.566 & 0.551 & 0.451 & 0.504 & 0.456 & 0.668 & 0.888 & & & \\
\hline $\mathbf{A U}$ & 0.638 & 0.652 & 0.646 & 0.617 & 0.422 & 0.678 & 0.501 & 0.455 & 0.457 & 1.000 & & \\
\hline PU & 0.712 & 0.631 & 0.624 & 0.635 & 0.465 & 0.574 & 0.735 & 0.506 & 0.494 & 0.534 & 0.823 & \\
\hline REA & 0.684 & 0.593 & 0.761 & 0.790 & 0.500 & 0.765 & 0.698 & 0.530 & 0.451 & 0.603 & 0.656 & 0.905 \\
\hline
\end{tabular}

Sumber: Data diolah 2019.

Tabel 5. Uji Reliabilitas

\begin{tabular}{|c|c|c|}
\hline & Cronbach's Alpha & Composite Reliability \\
\hline Attitude Toward Using & 0.781 & 0.874 \\
\hline Behavioral Intention & 0.819 & 0.917 \\
\hline Compatibility & 0.821 & 0.894 \\
\hline Convenience & 0.870 & 0.911 \\
\hline $\begin{array}{l}\text { Mobile } \\
\text { Knowledge }\end{array}$ & 0.806 & 0.885 \\
\hline Mobility & 0.832 & 0.899 \\
\hline Perceived Ease of Use & 0.899 & 0.930 \\
\hline $\begin{array}{l}\text { Perceived Security and } \\
\text { Privacy }\end{array}$ & 0.898 & 0.924 \\
\hline Perceived Trust & 0.909 & 0.937 \\
\hline Perceived Usage & 1.000 & 1.000 \\
\hline Perceived Usefulness & 0.840 & 0.893 \\
\hline Reachability & 0.779 & 0.900 \\
\hline
\end{tabular}

Sumber: Data diolah 2019

\section{Model struktural}

Model struktural digunakan untuk melakukan pengujian hipotesis Untuk mencari pembuktian apakah hipotesis diterima atau ditolak, maka penelitian ini menggunakan nilai koefisien path atau inner model yang menunjukkan tingkat signifikansi dalam pengujian hipotesis. Menurut Abdillah dan Jogiyanto (2015:197), 
skor koefisien path atau inner model menunjukkan tingkat signifikansi dalam pengujian hipotesis. Skor koefisien path atau inner model yang ditunjukkan oleh nilai T-statistic harus di atas 1,96 untuk hipotesis dua ekor (two-tailed) untuk pengujian hipotesis pada tingkat keyakinan $95 \%(\alpha=5 \%)$ atau 0,05 dan power $80 \%$. Jika nilai $T$-statistic $>T$-table yaitu 1,96, berarti hipotesis terdukung. Sebaliknya, jika nilai $T$-statistic $<T$-table, berarti hipotesis tidak terdukung. Berikut hasil Path Coefficient ditunjukkan pada tabel 6. Berdasarkan hasil dari tabel 6, dapat diketahui bahwa terdapat sepuluh hipotesis telah terdukung dan sebelas hipotesis yang tidak terdukung. Hipotesis yang tidak terdukung $(\mathrm{H} 1=0,857, \mathrm{H} 2=0,192, \mathrm{H} 3=0,223$, $\mathrm{H} 4=1,833, \mathrm{H} 6=0,368, \mathrm{H} 7=1,496, \mathrm{H} 8=0,294, \mathrm{H} 9=1,926, \mathrm{H} 10=1,102, \mathrm{H} 11=1,700$, H12=0,049) memiliki nilai $T$-statistic kurang dari 1,96.

Tabel 6. Path Coefficient (T-Statistic)

\begin{tabular}{|c|c|c|c|c|c|c|c|}
\hline & & $\begin{array}{c}\text { Original } \\
\text { Sample } \\
(\mathrm{O})\end{array}$ & $\begin{array}{c}\text { Sample } \\
\text { Mean } \\
\text { (M) }\end{array}$ & $\begin{array}{c}\text { Standard } \\
\text { Deviation } \\
\text { (STDEV) }\end{array}$ & $\begin{array}{c}\text { T-Statistics } \\
(|\mathrm{O} / \mathrm{STDEV}|)\end{array}$ & $\begin{array}{c}\text { P- } \\
\text { Values }\end{array}$ & Hasil \\
\hline H1 & MPK -> PEOU & 0.050 & 0.056 & 0.059 & 0.857 & 0.392 & $\begin{array}{c}\text { Tidak } \\
\text { Terdukung }\end{array}$ \\
\hline $\mathbf{H} 2$ & MOB -> PU & -0.021 & -0.017 & 0.107 & 0.192 & 0.848 & $\begin{array}{c}\text { Tidak } \\
\text { Terdukung }\end{array}$ \\
\hline H3 & MOB -> PEOU & -0.020 & -0.011 & 0.091 & 0.223 & 0.823 & $\begin{array}{c}\text { Tidak } \\
\text { Terdukung }\end{array}$ \\
\hline H4 & REA $->$ PU & 0.188 & 0.184 & 0.103 & 1.833 & 0.067 & $\begin{array}{c}\text { Tidak } \\
\text { Terdukung }\end{array}$ \\
\hline H5 & REA $->$ PEOU & 0.365 & 0.357 & 0.108 & 3.392 & 0.001 & Terdukung \\
\hline H6 & COM -> PU & 0.035 & 0.036 & 0.096 & 0.368 & 0.713 & $\begin{array}{c}\text { Tidak } \\
\text { Terdukung }\end{array}$ \\
\hline H7 & COM -> PEOU & 0.163 & 0.151 & 0.109 & 1.496 & 0.135 & $\begin{array}{c}\text { Tidak } \\
\text { Terdukung }\end{array}$ \\
\hline H8 & CON -> PU & 0.034 & 0.037 & 0.116 & 0.294 & 0.769 & $\begin{array}{c}\text { Tidak } \\
\text { Terdukung }\end{array}$ \\
\hline H9 & CON -> PEOU & 0.213 & 0.214 & 0.110 & 1.926 & 0.055 & $\begin{array}{c}\text { Tidak } \\
\text { Terdukung }\end{array}$ \\
\hline H10 & TR -> PEOU & 0.070 & 0.074 & 0.063 & 1.102 & 0.271 & $\begin{array}{c}\text { Tidak } \\
\text { Terdukung }\end{array}$ \\
\hline H11 & TR $->$ PU & 0.142 & 0.139 & 0.083 & 1.700 & 0.090 & $\begin{array}{c}\text { Tidak } \\
\text { Terdukung }\end{array}$ \\
\hline H12 & TR -> ATU & 0.004 & 0.000 & 0.074 & 0.049 & 0.961 & $\begin{array}{c}\text { Tidak } \\
\text { Terdukung }\end{array}$ \\
\hline H13 & TR -> BIU & 0.248 & 0.246 & 0.068 & 3.669 & 0.000 & Terdukung \\
\hline H14 & SP $->$ ATU & 0.251 & 0.264 & 0.083 & 3.024 & 0.003 & Terdukung \\
\hline H15 & PEOU -> PU & 0.479 & 0.485 & 0.084 & 5.670 & 0.000 & Terdukung \\
\hline H16 & PEOU $->$ ATU & 0.284 & 0.280 & 0.085 & 3.334 & 0.001 & Terdukung \\
\hline H17 & PU $>$ ATU & 0.375 & 0.369 & 0.087 & 4.281 & 0.000 & Terdukung \\
\hline H18 & PU -> BIU & 0.194 & 0.194 & 0.075 & 2.598 & 0.010 & Terdukung \\
\hline H19 & $\mathbf{P U}->\mathbf{A U}$ & 0.203 & 0.201 & 0.079 & 2.559 & 0.011 & Terdukung \\
\hline H20 & ATU -> BIU & 0.441 & 0.447 & 0.083 & 5.306 & 0.000 & Terdukung \\
\hline H21 & BIU $>$ AU & 0.524 & 0.527 & 0.084 & 6.263 & 0.000 & Terdukung \\
\hline
\end{tabular}

Sumber: Data diolah 2019. 


\section{Pengaruh Mobile Payment Knowledge terhadap Perceived Ease of Use}

Hasil dari analisis data menunjukkan T-statistic < T-table yaitu sebesar $0,857<1,96$ dan p-values sebesar 0,392. Hal ini menunjukkan bahwa mobile payment knowledge tidak berpengaruh signifikan terhadap perceived ease of use. Dengan demikian, H1 tidak terdukung. Hasil penelitian ini berbeda dengan penelitian terdahulu yang dilakukan oleh Kim (2010) yang membuktikan bahwa mobile payment knowledge memiliki pengaruh positif terhadap perceived ease of use.

Hasil penelitian ini tidak terdukung karena menurut beberapa responden wawancara online menyatakan bahwa tidak banyak pengguna yang mengenal begitu dekat terhadap penggunaan OVO dalam Grab. Mereka mengetahui info tersebut dari teman bahkan media sosial. Hal ini membuktikan jika seseorang tidak memiliki pengetahuan terkait dengan penggunaan OVO pada Grab, maka pengguna akan merasa sulit menggunakan OVO pada Grab sebagai metode pembayaran transaksi.

Sementara itu, hasil wawancara online ini didukung oleh pernyataan Haryanto dalam berita medcom.id yang mengungkapkan bahwa Indonesia masih tahap awal dalam pengenalan metode pembayaran digital. Edukasi menjadi salah satu tantangan yang dihadapi dalam mendorong gerakan non-tunai, sebab sebesar 90\% masyarakat di Indonesia masih menggunakan uang tunai sebagai alat pembayaran utama mereka. Tanpa edukasi, pengguna akan merasa enggan dan sulit dalam menggunakan ponsel mereka untuk transaksi sehari-hari, terutama transaksi yang menggunakan non tunai. Pengguna beranggapan bahwa penggunaan mobile payment OVO untuk tranportasi online Grab mudah digunakan, namun sebagian besar pengguna sudah terbiasa menggunakan cash atau uang tunai untuk transaksi sehari-hari. Dengan demikian, hasil penelitian ini menyatakan mobile payment knowledge tidak berpengaruh signifikan terhadap perceived ease of use.

\section{Pengaruh Mobility terhadap Perceived Usefulness}

Hasil dari analisis data menunjukkan T-statistic < T-table yaitu sebesar $0,192<1,96$ dan p-values sebesar 0,848. Hal ini menunjukkan bahwa mobility tidak berpengaruh signifikan terhadap perceived usefulness. Dengan demikian, H2 tidak terdukung. Hasil penelitian ini berbeda dengan penelitian terdahulu yang dilakukan Kim (2010) yang menyatakan bahwa mobility memiliki pengaruh positif terhadap 
perceived usefulness. Apabila seseorang tidak dapat menggunakan OVO pada Grab dimana saja dengan jaringan ponsel yang tidak stabil, maka pengguna akan sulit untuk melakukan transaksi pada layanan di Grab dan mendapatkan manfaat dari transaksi tersebut.

\section{Pengaruh Mobility terhadap Perceived Ease of Use}

Hasil dari analisis data menunjukkan T-statistic < T-table yaitu sebesar $0,223<1,96$ dan p-values sebesar 0,823. Hal ini menunjukkan bahwa mobility tidak berpengaruh signifikan terhadap perceived ease of use. Dengan demikian, H3 tidak terdukung. Hasil penelitian ini didukung penelitian terdahulu dari Kim (2010) yang menyatakan bahwa mobility memiliki pengaruh negatif terhadap perceived ease of use. Apabila seseorang tidak dapat menggunakan OVO pada Grab dimana saja dengan jaringan ponsel yang tidak stabil, maka pengguna akan sulit mengakses layanan di Grab.

\section{Pengaruh Reachability terhadap Perceived Usefulness}

Hasil dari analisis data menunjukkan T-statistic < T-table yaitu sebesar $1,833<1,96$ dan p-values sebesar 0,067. Hal ini menunjukkan bahwa reachability tidak berpengaruh signifikan terhadap perceived usefulness. Dengan demikian, H4 tidak terdukung. Hasil penelitian ini berbeda dengan penelitian terdahulu yang dilakukan oleh Kim (2010) yang menyatakan bahwa reachability memiliki pengaruh positif terhadap perceived usefulness. Apabila seseorang menggunakan OVO sebagai metode pembayaran pada Grab, maka pengguna akan susah menjangkau driver saat akan melakukan transkasi.

\section{Pengaruh Reachability terhadap Perceived Ease of Use}

Hasil dari analisis data menunjukkan T-statistic > T-table yaitu sebesar 3,392 > 1,96 dan p-values sebesar 0,001. Hal ini menunjukkan bahwa reachability berpengaruh signifikan terhadap perceived ease of use. Dengan demikian, H5 terdukung. Penelitian ini didukung oleh penelitian terdahulu yang dilakukan oleh Kim (2010) yang membuktikan bahwa reachability memiliki pengaruh positif terhadap perceived ease of use. Apabila seseorang menggunakan promo saat 
menggunakan OVO sebagai metode pembayaran pada Grab, maka pengguna akan menemukan driver dan melakukan transaksi sesuai pesanan penggna.

\section{Pengaruh Compatibility terhadap Perceived Usefulness}

Hasil dari analisis data menunjukkan T-statistic < T-table yaitu sebesar $0,368<1,96$ dan p-values sebesar 0,713. Hal ini menunjukkan bahwa compatibility tidak berpengaruh signifikan terhadap perceived usefulness. Dengan demikian, H6 tidak terdukung. Hasil penelitian ini sesuai dengan yang dilakukan oleh Kim (2010) bahwa compatibility tidak memiliki pengaruh yang signifikan terhadap perceived usefulness. Apabila seseorang mempunyai promo dari Grab dengan menggunakan OVO dan promo tersebut terbatas pemakaiannya, maka transaksi pengguna tidak bisa menyesuaikan dengan kebutuhan pengguna.

\section{Pengaruh Compatibility terhadap Perceived Ease of Use}

Hasil dari analisis data menunjukkan T-statistic < T-table yaitu sebesar 1,496 < 1,96 dan p-values sebesar 0,135. Hal ini menunjukkan bahwa compatibility tidak berpengaruh signifikan terhadap perceived ease of use. Dengan demikian, H7 tidak terdukung. Hasil penelitian ini didukung oleh penelitian terdahulu oleh Kim (2010) bahwa compatibility tidak memiliki pengaruh yang signifikan terhadap perceived ease of use. Apabila pihak Grab menerapkan sistem baru terutama pembayaran dengan menggunakan OVO, belum tentu semua pengguna paham untuk menggunakan OVO sebagai alat pembayaran pada Grab.

Pihak Grab mengatakan di situs web Grab sendiri bahwa kebijakan pembatalan baru masih akan memberikan penumpang flesibilitas untuk membatalkan pemesanan yang baru saja mereka buat dan pada saat yang sama memastikan pengemudi mendapat kompensasi yang adil atas waktu dan upaya mereka yang bepergian menuju pengguna. Pihak Grab juga mengatakan dalam emailnya bahwa kebijakan baru ini diperkenalkan untuk memungkinkan kelonggaran dalam keadaan yang terduga. Dengan pemberitahuan dan pembaruan sistem ini, tidak banyak pengguna yang mengerti maksud dan tujuan yang diberikan oleh Grab, sehingga dengan masalah tersebut akan membuat pengguna tidak mudah untuk menggunakan 
aplikasi untuk menyesuaikan kebutuhan hidupnya. Dengan demikian, compatibility tidak berpengaruh signifikan terhadap perceived ease of use.

\section{Pengaruh Convenience terhadap Perceived Usefulness}

Hasil dari analisis data menunjukkan T-statistic < T-table yaitu sebesar $0,294<1,96$ dan p-values sebesar 0,769. Hal ini menunjukkan bahwa convenience tidak berpengaruh signifikan terhadap perceived usefulness. Dengan demikian, H8 tidak terdukung. Hasil penelitian ini berbeda dengan dilakukan oleh Kim (2010) yang menyatakan bahwa convenience memiliki pengaruh yang signifikan terhadap perceived usefulness. Apabila terjadi kecurangan driver yang menarik saldo OVO secara diam-diam, maka pengguna akan merasa tidak nyaman menggunakan OVO sebagai metode pembayaran pada Grab.

Berdasarkan berita medan.tribunnews.com, wartawan tribunsumsel menemukan modus pemotongan saldo OVO yang dilakukan oknum di driver Grab nakal. Driver diam-diam memotong saldo OVO melebihi tarif yang disepakati di awal. Review pengguna menceritakan kehilangan saldo yang terjadi saat menggunakan pelayanan GrabCar. Sampai saat ini pengguna sudah melaporkan ke pihak Grab, namun belum ada tanggapan. Modus ini terjadi pada menu edit tarif pada aplikasi driver Grab. Sasaran yang dituju adalah pengguna yang terburu-buru dan tidak melihat driver menyelesaikan pemotongan tarif. Dengan masalah diatas, pengguna merasa tidak nyaman jika menggunakan OVO pada Grab saat akan melakukan transaksi sehari-hari. Dengan demikian, convenience tidak berpengaruh signifikan terhadap perceived usefulness.

\section{Pengaruh Convenience terhadap Perceived Ease of Use}

Hasil dari analisis data menunjukkan T-statistic < T-table yaitu sebesar $1,926<1,96$ dan p-values sebesar 0,055. Hal ini menunjukkan bahwa convenience tidak berpengaruh signifikan terhadap perceived ease of use. Dengan demikian, H9 tidak terdukung. Hasil penelitian ini berbeda dengan yang dilakukan oleh Kim (2010) yang menyatakan bahwa convenience memiliki pengaruh yang signifikan terhadap perceived usefulness. Selain itu, beberapa jawaban responden menyatakan bahwa penggunaan OVO pada Grab membuat nyaman karena mudah untuk 
digunakan. Apabila pihak Grab memperbaiki sistem, perbaikan sistem yang dilakukan membuat top-up pengguna bermasalah dan saldo pengguna tidak dapat digunakan sehingga membuat pengguna tidak nyaman untuk menggunakan OVO pada Grab.

Berdasarkan berita cnnindonesia.com, pengguna mengeluh tidak bisa menggunakan OVO yang terintegrasi dengan Grab di aplikasi Grab dan telah kehilangan saldo. Pantauan cnnindonesia.com lini masa akun resmi Grab Indonesia dibanjiri keluhan pengguna, sementara pihak Grab mengatakan saldo pengguna yang hilang lantaran ada pemeliharaan sistem yang sedang dilakukan perusahaan. Dengan masalah diatas, banyak pengguna yang merasa tidak nyaman akibat pemeliharaan sistem yang membuat saldo OVO hilang dan tidak dapat digunakan. Dengan demikian, convenience tidak berpengaruh signifikan terhadap perceived ease of use.

\section{Pengaruh Perceived Ease of Use terhadap Perceived Usefulness}

Hasil dari analisis data menunjukkan T-statistic > T-table yaitu sebesar 5,670 > 1,96 dan p-values sebesar 0.000. Hal ini menunjukkan bahwa perceived ease of use berpengaruh signifikan terhadap perceived usefulness. Dengan demikian, H10 terdukung. Hasil penelitian ini didukung oleh penelitian terdahulu yang dilakukan oleh Kim (2010), Nasri (2012), dan Martin (2014) yang membuktikan bahwa perceived ease of use memiliki pengaruh yang signifikan terhadap perceived usefulness. Apabila pengguna merasa mudah dalam menggunakan OVO pada Grab, maka pengguna akan merasa sangat bermanfaat dan akan menggunakannya lagi untuk transaksi lainnya.

Berdasarkan grab.com, fitur lebih dengan menggunakan OVO, pengguna dapat melihat saldo dan riwayat transaksi dalam fitur ini dan akan menemukan saldo dan riwayat transaksi. Kemudian, fitur tersebut dapat digunakan untuk transaksi apapun termasuk kebutuhan sehari-hari. Dalam penjelasan ini, fitur OVO dalam Grab dapat diterima pengguna dengan kemudahan penggunaan aplikasi Grab dengan metode pembayaran OVO. Berdasarkan alasan tersebut, maka perceived ease of use berpengaruh signifikan terhadap perceived usefulness. 


\section{Pengaruh Perceived Ease of Use terhadap Attitude Toward Using}

Hasil dari analisis data menunjukkan T-statistic > T-table yaitu sebesar 3,334 > 1,96 dan p-values sebesar 0,001. Hal ini menunjukkan bahwa perceived ease of use berpengaruh signifikan terhadap attitude toward using. Dengan demikian, H11 terdukung. Penelitian ini didukung oleh penelitian terdahulu yang dilakukan oleh Nasri (2012) dan Marakakandy (2017) yang membuktikan bahwa perceived ease of use memiliki pengaruh yang signifikan terhadap attitude toward using. Apabila pengguna merasa mudah dalam menggunakan OVO pada Grab, maka pengguna akan memberikan sikap positif terhadap penggunaannya.

Grab memberikan penjelasan mengenai manfaat apabila menggunakan uang tanpa tunai. Dengan menggunakan OVO pada Grab maka ketika akan melakukan transaksi, pengguna tidak perlu susah untuk melakukan pembayara, pembayaran aman, mendapatkan poin Grabrewards yang dapat dibelanjakan kembali dengan menggunakan poin tersebut dan apabila ada keluhan dapat menghubungi pihak Grab. Penjelasan diatas menjelaskan bahwa kemudahan yang terdapat pada penggunaan OVO di Grab akan memberikan sifat positif kepada pengguna. Dengan demikian, perceived ease of use berpengaruh signifikan terhadap attitude toward using.

\section{Pengaruh Perceived Usefulness terhadap Attitude Toward Using}

Hasil dari analisis data menunjukkan T-statistic > T-table yaitu sebesar 4,281 > 1,96 dan p-values sebesar 0,000. Hal ini menunjukkan bahwa perceived usefulness berpengaruh signifikan terhadap attitude toward using. Dengan demikian, H12 terdukung. Penelitian ini didukung oleh penelitian terdahulu yang dilakukan oleh Nasri (2012) dan Marakakandy (2017) yang membuktikan bahwa perceived usefulness memiliki pengaruh yang signifikan terhadap attitude toward using. Apabila pengguna merasa diuntungkan dengan banyaknya promo yang diberikan Grab jika menggunakan OVO, maka pengguna akan memberikan sikap positif terhadap manfaat dalam penggunaannya.

\section{Pengaruh Perceived Usefulness terhadap Behavioral Intention}

Hasil dari analisis data menunjukkan T-statistic > T-table yaitu sebesar 2,598 > 1,96 dan p-values sebesar 0,010. Hal ini menunjukkan bahwa perceived 
usefulness berpengaruh signifikan terhadap behavioral intention. Dengan demikian, H13 terdukung. Penelitian ini didukung oleh penelitian terdahulu yang dilakukan oleh Hwang (2003), Kim (2010), Nasri (2012), dan Marakakandy (2017) yang membuktikan bahwa perceived usefulness memiliki pengaruh yang signifikan terhadap behavioral intention. Apabila seseorang merasa OVO dapat memberikan banyak manfaat, maka minat pengguna dalam bertransaksi akan meningkat seiring dengan kemauan pengguna menggunakan OVO pada Grab.

Berdasarkan website Grab.com, Grab memperkenalkan GrabFresh dengan belanja kebutuhan sehari-hari yang bisa digunakan di aplikasi Grab. Hal ini ditujukan bagi pengguna yang sedang tidak punya waktu atau mood yang tidak sesuai untuk belanja keluar rumah. Pada aplikasi Grab juga diberitahu bagaimana cara penggunaannya dengan tutorial singkat yang ada di aplikasi Grab. Penjelasan tersebut menjelaskan bahwa dengan kegunaan menggunakan OVO pada aplikasi Grab, maka akan meningkatkan belanja pengguna. Dengan demikian, perceived usefulness berpengaruh signifikan terhadap behavioral intention.

\section{Pengaruh Perceived Usefulness terhadap Perceived Usage}

Hasil dari analisis data menunjukkan T-statistic > T-table yaitu sebesar 2,559 > 1,96 dan p-values sebesar 0,011. Hal ini menunjukkan bahwa perceived usefulness berpengaruh signifikan terhadap perceived usage. Dengan demikian, H14 terdukung. Penelitian ini didukung oleh penelitian terdahulu yang dilakukan oleh Igbaria (1995) yang membuktikan bahwa perceived usefulness memiliki pengaruh yang signifikan terhadap perceived usage. Apabila pengguna merasa memiliki manfaat dimulai dengan aktivasi pertama OVO pada Grab, maka pengguna akan menggunakan OVO pada Grab secara terus-menerus.

Berdasarkan website grab.com, penggunaan Rp1 memiliki syarat dan ketentuan bagi pengguna. Rp1 berlaku untuk perjalanan pertama setelah aktivasi OVO dengan tarif maksimal Rp 50.000. Tarif Rp1 diluar biaya tol dan parkir dan hanya berlaku bagi pengguna yang sudah aktivasi OVO di Grab dan menggunakan OVO sebagai metode pembayaran. Penjelasan tersebut menjelaskan bahwa dengan menggunakan OVO akan sesuai dengan kebutuhan pengguna sehari-hari. Dengan demikian, perceived usefulness berpengaruh signifikan terhadap perceived usage. 


\section{Pengaruh Attitude Towards Using terhadap Behavioral Intention}

Hasil dari analisis data menunjukkan T-statistic > T-table yaitu sebesar 5,306 > 1,96 dan p-values sebesar 0,000. Hal ini menunjukkan bahwa attitude towards using berpengaruh signifikan terhadap behavioral intention. Dengan demikian, H15 terdukung. Penelitian ini didukung oleh penelitian terdahulu yang dilakukan oleh Nasri (2012) dan Marakarkandy (2017) yang membuktikan bahwa attitude towards using memiliki pengaruh yang signifikan terhadap behavioral intention. Apabila seseorang sudah memiliki sikap positif saat melakukan transaksi dengan menggunakan OVO pada Grab, maka sikap tersebut akan meningkatkan minat pengguna dalam menggunakannya.

Menurut website grab.com, update cara bayar grab dengan pembayaran non tunai akan mendapatkan untung yang lebih besar, dan juga dapat menikmati banyak promo menarik seperti mendapatkan tarif super hemat untuk perjalanan. Penjelasan tersebut bahwa semakin banyak keuntungan yang diberikan maka minat pengguna akan belanja semakin tinggi dan akan memberikan sikap positif terhadap penggunaan metode pembayaran OVO pada Grab. Dengan demikian, behavioral intention berpengaruh signifikan terhadap attitude towards using.

\section{Pengaruh Behavioral Intention terhadap Perceived Usage}

Hasil dari analisis data menunjukkan T-statistic > T-table yaitu sebesar 6,263 > 1,96 dan p-values sebesar 0,000. Hal ini menunjukkan bahwa behavioral intention berpengaruh signifikan terhadap perceived usage. Dengan demikian, H16 terdukung. Penelitian ini didukung oleh penelitian terdahulu yang dilakukan oleh Hwang (2003), Martins (2014), dan Marakakandy (2017) yang membuktikan bahwa behavioral intention memiliki pengaruh yang signifikan terhadap perceived usage. Apabila seseorang memiliki minat belanja yang tinggi, maka pengguna akan menggunakan promo untuk melakukan transasksi karena lebih murah dan mudah dan akan digunakan terus-menerus.

\section{Pengaruh Perceived Trust terhadap Behavioral Intention}

Hasil dari analisis data menunjukkan T-statistic > T-table yaitu sebesar 3,669 > 1,96 dan p-values sebesar 0,000. Hal ini menunjukkan bahwa perceived trust 
berpengaruh signifikan terhadap behavioral intention. Dengan demikian, H17 terdukung. Penelitian ini berbeda dengan hasil penelitian yang dilakukan oleh Marakarkandy (2017) yang membuktikan bahwa perceived trust tidak memiliki pengaruh positif terhadap behavioral intention. Penelitian ini didukung oleh penelitian terdahulu yang dilakukan oleh Gefen (2003) yang membuktikan bahwa perceived trust memiliki pengaruh yang signifikan terhadap behavioral intention.

Selain itu, jawaban beberapa responden mengatakan bahwa mereka percaya menggunakan OVO karena Grab sudah ada sistem untuk menjaga identitas pribadi para pengguna sehingga pengguna tidak merasa khawatir apabila minat belanja tinggi dan menggunakan OVO pada Grab untuk melakukan transaksi. Apabila seseorang merasa percaya menggunakan OVO pada Grab karena Grab dapat menjaga data diri mereka dan memberikan estimasi waktu serta tarif yang baik, maka pengguna akan meningkatkan minat belanja mereka saat menggunakan OVO pada Grab.

Berdasarkan website Grab.com, menurut review pengguna, peningkatan paling utama dibanding layanan tranportasi yang ada adalah Grab telah memberikan estimasi waktu dan tarif yang lebih baik, memungkinkan pengguna untuk menghindari pembayaran tarif yang terlalu mahal serta memberikan layanan pengguna yang lebih cepat dan baik serta aman untuk digunakan. Penjelasan tersebut menjelaskan bahwa kepercayaan pengguna meningkatkan minat pengguna dalam melakukan transaksi sehari-hari. Dengan demikian, perceived trust berpengaruh signifkan terhadap behavioral intention.

\section{Pengaruh Perceived Trust terhadap Perceived Ease of Use}

Hasil dari analisis data menunjukkan T-statistic $<\mathrm{T}$-table yaitu sebesar $1,102<1,96$ dan p-values sebesar 0,271. Hal ini menunjukkan bahwa perceived trust tidak berpengaruh signifikan terhadap perceived ease of use. Dengan demikian, H18 tidak terdukung. Penelitian ini didukung oleh penelitian terdahulu yang dilakukan Marakarkandy (2017) yang membuktikan bahwa perceived trust tidak memiliki pengaruh positif terhadap perceived ease of use. Selain itu, jawaban beberapa responden mengatakan bahwa penyimpanan uang pada Grab demi kemudahan penggunaan memberikan kepercayaan karena Grab memiliki layanan service 24 jam 
unuk keluhan pengguna sehingga pengguna tidak perlu khawatir untuk menggunakan OVO pada Grab saat melakukan transaksi. Apabila seseorang merasakan pengalaman penipuan saat melakukan transaksi, maka akan menurunkan kepercayaan pengguna terhadap kemudahan penggunaan OVO pada Grab.

\section{Pengaruh Perceived Trust terhadap Perceived Usefulness}

Hasil dari analisis data menunjukkan T-statistic < T-table yaitu sebesar $1,700<1,96$ dan p-values sebesar 0,090. Hal ini menunjukkan bahwa perceived trust tidak berpengaruh signifikan terhadap perceived usefulness. Dengan demikian, H19 tidak terdukung. Penelitian ini didukung oleh penelitian terdahulu yang dilakukan oleh Marakarkandy (2017) yang membuktikan bahwa perceived trust memiliki pengaruh yang tidak signifikan terhadap perceived usefulness. Penelitian ini berbeda dengan hasil penelitian dari Gefen (2003) yang menunjukkan bahwa perceived trust berpengaruh positif terhadap perceived usefulness. Apabila seseorang melakukan transaksi dan tidak sesuai dengan kebutuhan serta mendapatkan hal yang merugikan, maka pengguna akan merasa bahwa penggunaan OVO pada Grab tidak memberikan manfaat lebih dalam bertaransaksi.

Berdasarkan grab.com, Grab memberikan kesempatan kepada pengguna sebagai salah satu dari kebijakan keamanan dan keselamatan adalah mengharuskan pengguna untuk membatalkan pesanan jika data atau informasi pengemudi yang menjemput berbeda dengan pemesanan pada aplikasi. Hal ini mengurangi terjadinya kasus-kasus yang tidak diinginkan dan meningkatkan keselamatan bagi pelanggan sehingga pelanggan dapat percaya untuk menggunakan OVO sebagai metode pembayaran pada transportasi online Grab. Alasan tersebut menjadikan masalah bahwa akan mengurangi kepercayaan pengguna dalam menggunakan pembayaran non-tunai saat akan melakukan transaksi. Dengan demikian, perceived trust tidak berpengaruh signifikan terhadap perceived usefulness.

\section{Pengaruh Perceived Trust terhadap Attitude Towards Using}

Hasil dari analisis data menunjukkan T-statistic < T-table yaitu sebesar $0,049<1,96$ dan p-values sebesar 0,961. Hal ini menunjukkan bahwa perceived trust tidak berpengaruh signifikan terhadap attitude towards using. Dengan demikian, H20 
tidak terdukung. Penelitian ini berbeda dengan hasil penelitian terdahulu yang dilakukan oleh Marakakandy (2017) yang membuktikan bahwa perceived trust memiliki pengaruh yang signifikan terhadap attitude towards using. Apabila seseorang mengalami penipuan dan membuat dirinya tidak percaya dalam penggunaan OVO pada Grab, maka pengguna akan memberikan sikap negatif terhadap penggunaannya jika akan melakukan transaksi.

Berdasarkan review pengguna dari news.detik.com yang menjelaskan bahwa pengguna sudah mengisi saldo OVO sebesar Rp 200.000 di Bank Mandiri dan mengisi kembali Rp 200.000, namun saldo tidak bertambah dan kemudian akun dibekukan. Hal ini ditanggapi oleh pihak Grab dengan menjawab bahwa akan terus meningkatkan kualitas sistem. Masalah diatas menjelaskan bahwa kepercayaan pengguna akan mempengaruhi sikap pengguna terhadap pemakaian OVO pada transportasi online Grab. Dengan demikian, perceived trust tidak berpengaruh signifikan terhadap attitude towards using.

\section{Pengaruh Perceived Security and Privacy terhadap Attitude Towards Using}

Hasil dari analisis data menunjukkan T-statistic > T-table yaitu sebesar 3,024 > 1,96 dan p-values sebesar 0,003. Hal ini menunjukkan bahwa perceived security and privacy berpengaruh signifikan terhadap attitude towards using. Dengan demikian, H21 terdukung. Penelitian ini didukung oleh penelitian terdahulu yang dilakukan oleh Nasri (2012) yang membuktikan bahwa perceived security and privacy memiliki pengaruh yang signifikan terhadap attitude towards using. Apabila seseorang merasa di kondisi gawat dan mendapatkan kejadian tidak diinginkan, maka pihak Grab memberikan fitur baru agar pengguna merasa aman dalam menggunakan OVO pada Grab dan pengguna percaya dalam keamanan privasi pengguna.

Berdasarkan medan.tribunnews.com, pengguna merasa dirugikan akibat saldo OVO yang dicuri secara diam-diam oleh driver. Grab baru saja mengeluarkan perubahan tarif pada aplikasi driver agar driver diberikan kemudahan dalam mengubah tarif jika tarif lebih murah atau lebih mahal. Namun, perubahan tersebut membawa dampak negatif terhadap keamanan dan privasi pengguna. Sehingga saat masalah ini terjadi dengan kasus driver mengganti tarif dengan mudah dan tidak sesuai dengan tarif yang ada, maka Grab menghilangkan fitur yang diberikan kepada 
driver. Hal ini dilakukan agar menjaga keamanan pengguna dalam menggunakan mobile payment OVO pada transportasi online Grab. Dari masalah diatas dijelaskan bahwa keamanan yang dirasakan oleh pengguna akan memberikan sikap positif terhadap penggunaan transportasi online Grab. Dengan demikian, perceived security berpengaruh signifikan terhadap attitude towards using.

\section{Kesimpulan, Implikasi, Saran dan Keterbatasan}

Hasil penelitian ini menunjukkan bahwa persepsi pengguna aplikasi transportasi Grab berpengaruh terhadap perilaku penggunaan mobile payment OVO. Beberapa hal yang mempengaruhi persepsi pengguna aplikasi transportasi Grab terhadap perilaku penggunaan mobile payment OVO yaitu kemudahan jangkauan, kepercayaan, serta keamanan dan privasi. Pertama, persepsi pengguna terhadap penggunaan aplikasi transportasi Grab memiliki pengaruh terhadap perilaku penggunanya karena aplikasi ini mudah dijangkau saat bertransaksi di merchantmerchant yang sudah bekerjasama dengan aplikasi tersebut. Kedua, Pengguna memiliki kepercayaan terhadap aplikasi Grab terutama saat menggunakan mobile payment OVO karena pihak Grab mampu menjaga data pribadi pengguna sehingga memiliki pengaruh terhadap perilaku pengguna untuk terus menggunakan aplikasi tersebut. Ketiga, mobile payment OVO pada transportasi online Grab dapat menjaga keamanan dan privasi penggunanya.

Selanjutnya, beberapa hal yang tidak memiliki pengaruh terhadap perilaku pengguna mobile payment OVO pada transportasi online Grab yaitu minimnya pengetahuan yang dimiliki oleh pengguna, ketidakstabilan jaringan, ketidakpercayaan terhadap saldo yang disimpan. Hal ini berdampak pada ketidaknyamanan pengguna untuk menggunakan mobile payment OVO belum bisa menyesuaikan dengan kebutuhan hidup pengguna. Sementara itu, faktor yang membuat pengguna kurang percaya untuk menggunakan OVO pada Grab karena banyaknya penipuan yang terjadi dan pesanan yang tidak sesuai dengan kebutuhan pengguna ataupun saldo OVO pada aplikasi transportasi Grab terpotong dan tidak sesuai dengan nominal transaksi sehingga pengguna juga merasa tidak aman. Di sisi lain, penelitian ini memiliki keterbatasan dari tingkat responsivitas responden dalam ketersediaan mengisi kuesioner yang sudah disebarkan melalui link google form. 
Diharapkan penelitian selanjutnya melakukan penelitian serupa dengan objek penelitian berbeda.

\section{Referensi}

Abdillah, Willy dan Jogiyanto. 2015. Partial Least Square (PLS). Penerbit Andi. Yogyakarta.

Andre. 2018. Top up Berhasil, Saldo OVO tidak Bertambah. https://news.detik.com/suara-pembaca/d-3841215/top-up-berhasil-saldo-ovotidak-bertambah. Diakses tanggal 23 Maret 2019.

Anggraeni, Luthfi. 2019. Edukasi, Tantangan Besar Inklusi Keuangan. https://www.medcom.id/teknologi/tech-and-life/RkjRAOGk-edukasitantangan-besar-inklusi-keuangan. Diakses tanggal 8 Maret 2019.

Anggraini Tiara. 2018. Driver Online Nakal Dian-diam Curi Saldo OVO Anda, Begini Cara Menghindarinya. http://medan.tribunnews.com/2018/12/15/driveronline-nakal-diam-diam-curi-saldo-ovo-anda-begini-caramenghindarinya?page $=4$. Diakses tanggal 19 Maret 2019.

Ayuwuragil, Kustin. 2018. Grab Kenalkan Tombol 'Darurat' Saat Pengguna Merasa Tak Aman. https://www.cnnindonesia.com/teknologi/20180521133613-185299966/grab-kenalkan-tombol-darurat-saat-pengguna-merasa-tak-aman.

Diakses tanggal 5 April 2019.

Davis, Fred D. 1989. "Perceived Usefulness, Perceived Ease of Use, and User Accepatnce of Information Technology". Management Information Systems Research Center. Vol.13. (September). No.3: 319-340.

Davis, Fred D., Bagozzi, Richard P., and Paul R Warshaw. 1989. "User Acceptance of Computer Technology: A Comparison of Two Theoretical Models". Management Science. Vol. 35. (August). No. 8: 982-1003.

Gefen, David., Karahanna, Elena., and Detmar W Straub. 2003. "Trust and TAM in online shopping: An integrated model". Departement of Management. Vol. 27. (March). No.1: 51-90.

Grab. 2018. Pengguna tidak dapat menggunakan Kode Promo.

https://help.grab.com/passenger/id-id/115005848668-Kode-promo-tidak-dapatdigunakan. Diakses tanggal 5 April 2019.

Grab. 2019. Aplikasi sehari-hari dan keamanan sehtiap hari.https://www.grab.com/id/safety/. Diakses tanggal 5 April 2019.

Grab. 2019. Aktifkan OVO sekarang, Naik Grab Rp 1 saja! https://www.grab.com/id/blog/aktifkan-ovo-sekarang-naik-grab-rp1-aja/.

Diakses tanggal 5 April 2019.

Grab. 2019. Belanja kebutuhan sehari-hari dengan GrabFresh. https://www.grab.com/id/fresh/. Diakses tanggal 5 April 2019.

Grab. 2019. Pembayaran Grab tanpa Uang Tunai. https://www.grab.com/id/payment/. Diakses tanggal 5 April 2019.

Hartono, Jogiyanto. 2017. Metodologi Penelitian Bisnis Salah Kaprah dan Pengalaman-Pengalaman. BPFE. Yogyakarta.

Herlina, Kartika. 2018. Top up GrabPay aktif kembali, begini transaksi GrabPay dengan OVO. https://keuangan.kontan.co.id/news/top-up-grabpay-aktifkembali-begini-transaksi-grabpay-dengan-ovo\# Diakses tanggal 29 Agustus 2018. 
Hwang, Yujong., and Mun Y. Yi. 2003. "Predicting the use of web-based information systems: self-efficacy, enjoyment, learning goal orientation, and the technology acceptance model". International Journal of Human-Computer Studies. (February). pp. 431-449.

Jogiyanto. 2007. Sistem Informasi Keperilakuan. Andi. Yogyakarta.

Kesharwani, Ankit., and Shailendra Singh Bisht. 2011. "The impact of trust and perceived risk on internet banking adoption in India: An extension of technology acceptance model". International Journal of Bank Marketing. Vol. 30. (August). No.4: 303-322.

Kim, Changsu., Mirusmonov, Mirsobit., and In Lee. 2010. "An Empirical Examination of Factors Influencing the Intention to Use Mobile Payment". Departemen of Information Systems and Decision Sciences. (December). pp. 310-322.

Liu, Gia-Shie., and Pham Tan Tai. 2015. "An Analysis of Factors Affecting the Intention to Use Mobile Payment Services in Vietnam". Asia-Pasific Conference on Global Business, Economics, Finance and Social Sciences. (July). pp. 1-21.

Marakarkandy, Bijith., Yajnik, Nilay., and Chandan Dasgupta. 2017. "Enabling internet banking adoption: An empirical examination with an augmented technology acceptance model (TAM)". Journal of Enterprise Information Management. Vol. 30. (October). No.2: 263-294.

Martins, Carolina., Oliveira, Tiago., and Ales Popovic. 2013. "Understanding the Internet Banking Adoption: A Unified Theory of Acceptance and Use of Technology and Perceived Risk Application". International Journal of Information Management. (June). pp. 1-13.

Muhardiansyah.2018. Jalankan order fiktif, 8 driver Grab di median ditangkap polisi. https://www.merdeka.com/peristiwa/jalankan-order-fiktif-8-driver-grab-dimedan-ditangkap-polisi.html. Diakses tanggal 15 Maret 2019

Nasri, Wadie., and Lanouar Charfeddine. 2012. "Factors affecting the adoption of Internet banking in Tunisia: An integration theory of acceptance model and theory of planned behavior". Journal of High Technology Management Research. Vol. 23. (March). pp. 1-14.

Peraturan Bank Indonesia, Surat Keputusan No.19/12/PBI/2017 tentang Penyelenggaraan Teknologi Finansial.

Putro, Guntur. 2017. Transportasi Online dan Konvensional harus kolaborasi. https://www.cnnindonesia.com/ekonomi/20170325233255-92202770/transportasi-online-dan-konvensional-harus-kolaborasi. tanggal 10 Maret 2019.

Santosa, Paulus Insap. 2018. Metode Penelitian Kuantitatif: Pengembangan Hipotesis dan Pengujiannya menggunakan SmartPLS. Andi. Yogyakarta.

Sekaran, Uma., and Bougie Roger. 2016. Reasearch Methods for Business: A SkillBuilding Approach. United Kingdom.

Sitepu, Mehulika. 2017. Mengapa transportasi online di daerah masih kisruh di berbagai daerah? https://www.bbc.com/indonesia/indonesia-41597863. Diakses tanggal 20 Februari 2019.

Tim, CNN Indonesia. 2018. Netizen Keluhkan Saldo OVO di Grab Lenyap Saat Jam Sibuk.https://www.cnnindonesia.com/teknologi/20181012182212-185- 
338057/netizen-keluhkan-saldo-ovo-di-grab-lenyap-saat-jam-sibuk. Diakses tanggal 20 Maret 2019.

Ulfa, Wan. 2017. GrabPay yang Dihindari Para Driver. https://tirto.id/grabpay-yangdihindari-para-driver-coW9. Diakses tanggal 12 Maret 2019.

Venkatesh, Viswanath., and Fred D.Davis. 2000. "A Theoretical Extension of the Technology Acceptance Model: Four Longitudinal Field Studies". Management.

Zavolokina, Liudmila., Dolata, Mateusz., and Gerhard Schwabe. 2016. "Fintech What's in a Name?". International Conference on Information Systems. (December). pp. 1-19. 